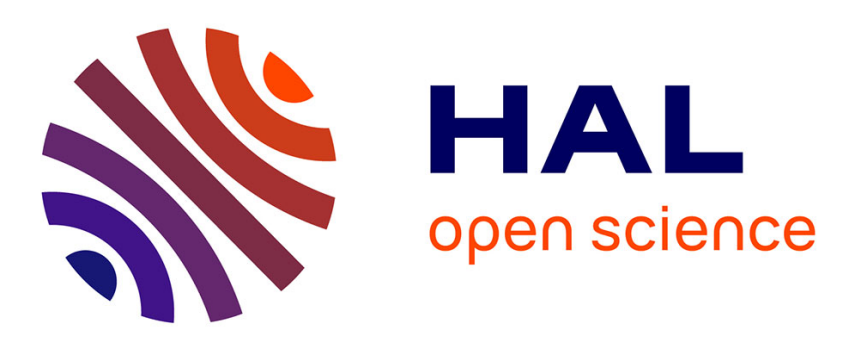

\title{
Omic Analysis of the Sepia officinalis White Body: New Insights into Multifunctionality and Haematopoiesis Regulation
}

\author{
Louis Benoist, Erwan Corre, Benoit Bernay, Joël Henry, Céline \\ Zatylny-Gaudin
}

\section{To cite this version:}

Louis Benoist, Erwan Corre, Benoit Bernay, Joël Henry, Céline Zatylny-Gaudin. Omic Analysis of the Sepia officinalis White Body: New Insights into Multifunctionality and Haematopoiesis Regulation. Journal of Proteome Research, 2020, 19 (8), pp.3072-3087. 10.1021/acs.jproteome.0c00100 . hal02965333

\section{HAL Id: hal-02965333 \\ https://hal.science/hal-02965333}

Submitted on 24 Jun 2021

HAL is a multi-disciplinary open access archive for the deposit and dissemination of scientific research documents, whether they are published or not. The documents may come from teaching and research institutions in France or abroad, or from public or private research centers.
L'archive ouverte pluridisciplinaire HAL, est destinée au dépôt et à la diffusion de documents scientifiques de niveau recherche, publiés ou non, émanant des établissements d'enseignement et de recherche français ou étrangers, des laboratoires publics ou privés. 


\title{
-Omic analysis of Sepia officinalis white body:
}

\author{
new insights into multifunctionality and
}

\section{haematopoiesis regulation}

Louis Benoist $^{1,2}$,Erwan Corre ${ }^{3}$, Benoit Bernay ${ }^{4}$, Joel Henry ${ }^{1,2}$, Céline Zatylny-Gaudin ${ }^{1,2, *}$

${ }^{1}$ NORMANDIE UNIV, UNICAEN, CNRS, BOREA, 14000 CAEN, France

${ }^{2}$ Laboratoire de Biologie des Organismes et Ecosystèmes Aquatiques (BOREA) Université de CaenNormandie, MNHN, SU, UA, CNRS, IRD, Esplanade de la paix, 14032 Caen Cedex, France

${ }^{3}$ Plateforme ABiMS, Station Biologique de Roscoff (CNRS-Sorbonne Université), 29688 Roscoff, France

${ }^{4}$ Plateforme PROTEOGEN, SF 4206 ICORE, Normandie Univ, Esplanade de la Paix, 14032 Caen Cedex, France

*Corresponding author: celine.gaudin@unicaen.fr 


\begin{abstract}
Cephalopods, like other Protostomes, lack an adaptive immune system and only rely on an innate immune system. The main immune cells are haemocytes, able to respond to pathogens and external attacks. First reports based on morphological observations suggested that the white body located in the optic sinuses of cuttlefish was at the origin of haemocytes. Combining transcriptomic and proteomic analyses, we identified several factors known to be involved in haematopoiesis in Vertebrate species in cuttlefish white body. Among these factors, members of the JAK-STAT signalling pathway were identified, some of them for the first time in a molluscan transcriptome and proteome. Immune factors such as members of the Toll/NF- $\mathrm{kB}$ signalling pathway, pattern recognition proteins and receptors, and members of the oxidative stress responses were also identified, and support an immune role of the white body. Both transcriptome and proteome analyses revealed that the white body harbours an intense metabolism concurrent with the haematopoietic function. Finally, a comparative analysis of the white body and haemocyte proteomes revealed many proteins in common, confirming previous morphological studies on the origin of haemocytes in cuttlefish. This molecular work demonstrates that the white body is multifunctional and provides bases for haematopoiesis regulation in cuttlefish.
\end{abstract}

KEYWORDS: Sepia officinalis, mollusc, white body, haematopoiesis, JAK-STAT pathway

\title{
Introduction
}

Protostomes only rely on their innate immune system to protect themselves against pathogens, whereas Vertebrate species possess both an innate and an adaptive immune systems. The innate immune system includes the cellular response and the humoral response. The 
cellular response involves circulating cells - haemocytes (Hct) - in Protostomes. Hct play a key immune role and are involved in antimicrobial factor release, melanisation, pathogen encapsulation or phagocytosis.

The different types of haemocytes among Protostomes are classified according to the degree of granulation, cytochemical staining and/or morphology. In Insects, six types of Hct have been described: prohaemocytes, plasmatocytes, granulocytes, cystocytes, spherulocytes (or adipohaemocytes) and oenocytoids (called crystal cells in Drosophila) ${ }^{1}$. Granulocytes and plasmatocytes are involved in phagocytosis, cystocytes in clotting and cell aggregation, and oenocytoids in prophenoloxidase (proPO) synthesis ${ }^{2,3}$. In Crustaceans, Hct are involved in phagocytosis, clotting, viral defence and proPO production. Three types of Hct have been described, namely the hyaline, granular, and semigranular cells ${ }^{1,4}$.

In Molluscs, the second largest phylum of Protostomes, one to four types of haemocytes have been described depending on the species and the descriptive criteria. Three types of Hct have been found in the gastropod Biomphalaria glabrata. In the two marine snails Aplysia californica and Megathura crenulate, and the freshwater snail Viviparus ater, only one type of Hct able to perform phagocytosis has been described ${ }^{6,7}$. In the Bivalves Crassostrea virginica, Mytilus galloprovincialis and Scrobicularia plana, three types of Hct have been identified, namely agranular hyalinocytes, basophilic granulocytes, and eosinophilic (acidophilic) granulocytes $^{8-10}$. In clam (Ruditapes philippinarum), only hyalinocytes and acidophilic granulocytes have been observed ${ }^{11}$, and granulocytes showed higher phagocytic activity than hyalinocytes $^{8,11}$.

Few studies have been performed on Cephalopod Hct. In Octopus vulgaris, two types of granulocytes have been described ${ }^{12-14}$. In Sepia officinalis, only one type of Hct, capable of phagocytosis and possessing acid phosphatase, lysozyme and proPO system enzymes has been described ${ }^{15,16}$. 
The haematopoietic organ (HPO) is the seat of Hct production and maturation. It is highly variable among Protostomes and has mainly been described by cytological and immunohistochemical studies. In Insects, the HPO or lymph glands are located along the anterior portion of the dorsal vessel ${ }^{2,17-19}$. In Crustaceans, the HPO is generally composed of gland-like lobules located on the dorsal portion, surrounding the ophthalmic artery ${ }^{4}$ HPO localisation differs in Molluscs. In the gastropod B. glabrata, the HPO is called the amebocyteproducing organ (APO) and is located at the basal surface of the pericardial epithelium ${ }^{20,21}$. In Bivalves, immunohistochemistry staining revealed that a stem cell marker (sox2) and an Hctspecific enzyme (the $\mathrm{Cu} / \mathrm{Zn}$ superoxide dismutase ( $\mathrm{Cu} / \mathrm{Zn} \mathrm{SOD})$ ) were co-expressed in the irregularly folded structure (IFS) found in the gills of the Pacific oyster Crassostrea gigas ${ }^{22}$. The authors suggested the involvement of this structure in haematopoiesis.

Knowledge on the drivers of haematopoiesis in Protostomes remains limited and restricted to only a few models such as Drosophila melanogaster ${ }^{23-25}$ and Pacifastacus leniusculus ${ }^{26,27}$. However, hardly any homologues of signalling pathways and factors involved in haematopoiesis have been identified in Molluscs. Cytokines are involved in many functions including haematopoiesis in Vertebrates; some of them have been identified in gastropods, such as IL-like and TNF $\alpha$-like molecules ${ }^{28}$ or the macrophage migration inhibitory factor (MIF) ${ }^{29,30}$. MIF, an evolutionarily conserved multifunctional protein, has been characterized in both Haliotis diversicolor supertexta ${ }^{30}$ and B. glabrata $^{29}$. In B. glabrata, BgMIF seems to be necessary for Hct activation in response to the parasite Schistosoma mansoni ${ }^{29}$. In Crassostrea gigas, GATA3, a haematopoietic transcription factor homologue $\mathrm{e}^{31,32}$, is expressed in the gills and in Hct, and overexpressed in the gills following a secondary challenge with the pathogenic bacteria Vibrio splendidus, suggesting a role in haematopoiesis ${ }^{33,34}$. The transcription factor Tal-1/Scl (Stem Cell Leukemia) is involved in embryonic haematopoiesis in human cells ${ }^{35}$; it 
was identified in Crassostrea gigas, where it is involved in the regulation of Hct-specific genes, such as Integrin, GATA3, c-Myb, c-kit or EcSOD ${ }^{36}$.

In cuttlefish and octopus, the white body (WB), located in the optic sinuses and composed of interconnected lobes, has been defined as the HPO, from on morphological and cytological observations $^{37-39}$. Claes studied the morphology of the WB in cuttlefish. The WB is a paired organ organized in interconnected lobes surrounding the optic tracts. High vascularization has been described, and is ensured by two branches of the cephalic aorta, the left and right ophthalmic arteries. Claes described four cell types according to cytomorphological properties: haemocytoblast, primary leucoblast, secondary leucoblast, and haemocyte. Based on cytological differences between these cell types, Claes concluded that they represent different stages of development and proposed a pathway for Hct maturation from a stem cell-like entity - the haemocytoblast - to a mature Hct, supporting the haematopoietic function of the $\mathrm{WB}^{37}$. Only two molecular studies have been performed on the WB in Euprymna tasmanica ${ }^{40}$ and Octopus maya ${ }^{41}$. Based on transcriptomic and gene ontology (GO) analysis, Salazar and collaborators identified 8 transcripts with homology to genes involved in haematopoiesis in other organisms, and 16 transcripts involved in the immune response ${ }^{40}$. Juárez and collaborators confirmed the occurrence of haematopoietic transcripts in $O$. maya white body and the downregulation of immune genes in fertilized females ${ }^{41}$. These results suggest a dual role of the WB in the regulation of the immune system and haematopoiesis. However, no complete signalling pathway underlying haematopoiesis has been identified so far.

The Janus kinase-signal transducer and activator of transcription (JAK-STAT) signalling pathway is involved in haematopoiesis in Vertebrates ${ }^{42,43}$, and has been described in Drosophila melanogaster $^{25,44}$. The JAK-STAT pathway is a membrane-to-nucleus mechanism allowing rapid regulation of gene transcription; it is activated by cytokines through cytokine receptors ${ }^{45}$. Four JAK and seven STATs have been described in mice ${ }^{43}$, while only one JAK and one STAT 
have been identified in Drosophila melanogaster ${ }^{46}$. In Molluscs, several STATs have been identified in Bivalves, Gastropods and Cephalopods ${ }^{41,47-50}$. In Hyriopsis cumingii, three STATs have been identified, and are involved in antimicrobial peptide expression ${ }^{48}$. In Pinctada fucata, a STAT homologue is expressed in several tissues including heart, gonad, gill or muscle. Overexpression was observed in the haemolymph after polyinosinic-polycytidylic acid (poly(I:C)) injection, suggesting a role in the immune response ${ }^{49}$. In B. glabrata, several transcription factors, including two STATs (STAT1 and STAT2) have been identified; they were up-regulated in Hct $12 \mathrm{~h}$ and $6 \mathrm{~h}$ after challenge with S. mansoni, respectively ${ }^{47}$. In Haliotis discus discus, a STAT5 homologue was expressed in all tested adult tissues, and upregulated in gills and Hct after challenge with $V$. parahaemolyticus, Listeria monocytogenes or poly(I:C) injection $^{50}$. Altogether, these results suggest that STATs are involved in the immune response of Molluscs. However, no complete JAK-STAT pathway has been identified in Molluscs, and only a few JAK-STAT pathway components have been described in Cephalopods ${ }^{41}$.

The aim of this study is to characterise the transcriptome and for the first time the HPO proteome of the cuttlefish (Sepia officinalis). A proteomic analysis coupled with transcriptomic data provides essential information to (1) further investigate the molecular processes involved in haemocyte formation, and (2) identify other additional functions of the WB.

\section{Materials \& Methods}

\section{Animals}

All cuttlefish were trapped in the Bay of Seine between January and June 2017. They were maintained in $1,000-\mathrm{L}$ outflow tanks at $16^{\circ} \mathrm{C}$ at the Centre de Recherches en Environnement Côtier (CREC, marine station of the University of Caen, Luc-sur-Mer, France). 


\section{Ethical statement}

This research followed the guidance given by Directive 2010/63/EU, and French regulations regarding the use of animals for experimental procedures. It was approved by the Regional Ethical Committee Cenomexa (Committee agreement number 54; project agreement number 03145.03). The experiment was designed to decrease animal distress by minimising the number of animals. Moreover, the tanks were modified so as to provide hiding places for cuttlefish.

Cuttlefish were anaesthetised with ethanol 3\%. After exsanguination, the white bodies were dissected, frozen in liquid nitrogen and stored at $-80{ }^{\circ} \mathrm{C}$ until mRNA isolation and protein extraction. Hct were separated from the haemolymph by centrifugation. Pellets were frozen in liquid nitrogen and stored at $-80^{\circ} \mathrm{C}$ until $\mathrm{mRNA}$ and protein extractions.

\section{Illumina sequencing}

RNA extraction was performed as described by Cornet and collaborators ${ }^{51}$. Briefly, total RNA from five white bodies from male cuttlefish was extracted using TriReagent (SigmaAldrich). After RNA analysis, library preparation and sequencing were conducted by the McGill University and Génome Québec Innovation Centre (Montréal, Québec, Canada) following the manufacturer's instructions (Illumina, San Diego, CA). The detailed protocol is available in the supporting experimental section. These data were submitted to SRA Bioproject PRJNA599385, Biosample SAMN13747092, with Accession number SRR10843375.

\section{Bioinformatic analysis}

Bioinformatic analysis (transcriptome assembly and annotation) was performed on RNA sequencing data from the white body organ. Raw sequencing data corresponded to a total of $43,361,848$ paired-end reads with a maximum read length of $150 \mathrm{bp}$. The raw dataset was filtered and cleaned using Trimmomatic $\mathrm{v}(0.36)^{52}$, using the following parameters: 
ILLUMINACLIP: adapt.fa: 2: 30: 10, LEADING: 5, TRAILING: 5, SLIDING WINDOW: 4:

5, MINLEN: 25. The overall sequence quality was checked using FastQC (v 0.11.5) (https://www.bioinformatics.babraham.ac.uk/projects/fastqc). Overall assembly was done with Trinity $2.4 .0 .^{53}$, a package dedicated to de novo transcriptomic assembly. A normalisation step was performed according to the kmer coverage ( $25 \mathrm{nt}$ kmer, maximum coverage 30 ) proposed by the Trinity package. Relative abundance was estimated using the pseudo aligner Kallisto ${\mathrm{v} 0.43 .1^{54}}$

The transcriptome was annotated using the Trinotate protocol (https://github.com/Trinotate/Trinotate.github.io), as described by Bryant and collaborators ${ }^{55}$. $\begin{array}{llll}\text { Proteins } & \text { were } & \text { predicted } & \text { TransDecoder }\end{array}$ (https://github.com/TransDecoder/TransDecoder). The search for similarity (blastx of the transcripts and blastp of the predicted proteins) was performed against the uniprot-swissprot database (version 2017-01). Signal peptides were predicted using the signal P utility v4.1 ${ }^{56}$. Transmembrane domains were detected using TMHMM v2.0c ${ }^{57}$. The protein domain search was performed using hmmscan of the hmmer suite v.3.1b1 against the Pfam-A database ${ }^{58}$. Finally, the functional annotation of the transcriptome was performed using the Trinotate pipeline. An annotation-based search was performed to identify relevant transcripts involved in several functions such as haematopoiesis or the immune and stress responses. Additionally, a manual search for conserved domains and patterns of known Invertebrate factors involved in haematopoiesis and the immune response was performed using a homemade software program called Peptraq as previously described by Zatylny-Gaudin and collaborators ${ }^{59}$. The presence of other relevant proteins from NCBI nr database was considered by using them as query sequences for the BLAST search against the WB transcriptome. For some proteins, molecular weights (MW) were calculated with the ExPASy ProtParam tool (https://web.expasy.org/protparam/). Specific domains were predicted using the InterPro 
(http://www.ebi.ac.uk/interpro/) ${ }^{60}$ and SMART (http://smart.embl-heidelberg.de/) $)^{61}$ tools. Multiple sequence alignment was performed using CLC Main Workbench 8 (CLC BIO). KEGG annotation was performed using the KAAS (KEGG Automatic Annotation Server) tool for transcriptome analysis ${ }^{62}$ and the BlastKOALA (KEGG Orthology And Links Annotation, version 2.2) tool for proteome analysis ${ }^{63}$.

\section{Protein extraction}

Whites bodies $(n=3)$ and Hct pellets $(n=3)$ were crushed in liquid nitrogen and then resuspended in PBS (phosphate buffered saline) with a cocktail of protease inhibitors (Sigma P2714). Extracts were centrifuged for 10 minutes at $20,000 \mathrm{~g}$ at $4^{\circ} \mathrm{C}$, and supernatants were recovered. Protein concentrations were determined using the BCA (bicinchoninic acid) assay ${ }^{64}$.

\section{SDS-PAGE-MALDI-MS proteome analysis}

Each white-body protein extract $(60 \mu \mathrm{g})$ was separated on a sodium dodecyl sulphate polyacrylamide electrophoresis (SDS-PAGE) gel (Tris-HCl 4-12\%) for $3 \mathrm{~h}$ at $120 \mathrm{~V}$ in Tris-HCl migration buffer (25 mM Tris- $\mathrm{HCl} \mathrm{pH} 8.3,192 \mathrm{mM}$ glycine, $0.1 \%$ SDS $)$ with a broad-range protein molecular weight marker (Promega V8491). Gels were stained with a methanol 40\% acetic acid $10 \%$ solution containing $0.1 \%$ Coomassie blue. High-intensity spots were cut off into slices to analyse highly abundant proteins. After discolouration, slices were reduced with 50mM dithiothreitol (DTT), alkylated with $55 \mathrm{mM}$ iodoacetamide (IAA) and hydrolysed with $0.006 \mu \mathrm{g} / \mu 1$ trypsin solution. MALDI-MS experiments were performed as described in Cornet and collaborators ${ }^{65}$. 


\section{NanoLC ESI-MS analysis of the white body and haemocyte proteomes}

For a comparative study between the WB and Hct extracts, $10 \mu \mathrm{g}$ of each whole WB and Hct extract $(\mathrm{n}=3)$ were reduced with $10 \mathrm{mM}$ DTT, alkylated with 20mM IAA, and hydrolysed with $0,006 \mu \mathrm{g} / \mu 1$ trypsin solution.

For nanoLC fragmentation, the resulting peptide samples were first desalted and concentrated onto a $\mu \mathrm{C} 18$ Omix column (Agilent) before analysis. The chromatography step was performed on a NanoElute (Bruker Daltonics) ultra-high-pressure nano flow chromatography system (nanoLC). Two hundred nanograms of peptides were concentrated onto a C18 pepmap 100 (5mm x $300 \mu \mathrm{m}$ i.d.) precolumn (Thermo Scientific) and separated at $50^{\circ} \mathrm{C}$ on a reversed-phase Reprosil column $(25 \mathrm{~cm} \times 75 \mu \mathrm{m}$ i.d.) packed with $1.6 \mu \mathrm{m} \mathrm{C} 18$ coated porous silica beads (Ionopticks). Mobile phases consisted of $0.1 \%$ formic acid in $99.9 \%$ water (v/v) (A) and $0.1 \%$ formic acid in $99.9 \% \mathrm{ACN}(\mathrm{v} / \mathrm{v})(\mathrm{B})$. The nanoflow rate was set at $400 \mathrm{nl} / \mathrm{min}$, and the gradient profile was as follows: from 2 to $15 \% \mathrm{~B}$ within $60 \mathrm{~min}$, followed by an increase to $25 \% \mathrm{~B}$ within 30 min and further to $37 \%$ within $10 \mathrm{~min}$, followed by a washing step at $95 \%$ B and reequilibration.

ESI-MS experiments were carried out on an TIMS-TOF pro mass spectrometer (Bruker Daltonics) with a modified nano electrospray ion source (CaptiveSpray, Bruker Daltonics). The system was calibrated every week, and mass precision was better than $1 \mathrm{ppm}$. A 1400 spray voltage with a capillary temperature of $180^{\circ} \mathrm{C}$ was typically employed for ionizing. MS spectra were acquired in the positive mode in the $100-1700 \mathrm{~m} / \mathrm{z}$ mass range. The mass spectrometer was operated in PASEF mode with exclusion of single charged peptides. A number of 10 PASEF MS/MS scans were performed within 1.25 seconds from charge range 2-5. 


\section{Peptide Sequencing and Protein Precursor Identification}

The fragmentation pattern was used to determine the sequence of each peptide. Database searching was performed using Peaks X software. Using a homemade software programme called Peptraq, each transcript from the WB transcriptome was translated in all six reading frames, with a cut-off to delete sequences $<40$ amino acids. This database, which possesses 361,796 entries, was used for MS identifications. The variable modifications allowed were as follows: C-carbamidomethyl, K-acetylation, methionine oxidation, and deamidation (NQ). “Trypsin" was selected as semi-specific. Mass accuracy was set to $40 \mathrm{ppm}$ and $0.05 \mathrm{Da}$ for the MS and MS/MS modes, respectively. Data were filtered according to an FDR of 1\%, 2 unique peptides and the elimination of protein redundancy on the basis of proteins being evidenced by the same set or a subset of peptides. iBAQ (Intensity-Based Absolute Quantification) analysis was performed by normalising MS intensities with putative average molecular weights. The mass spectrometry proteomics data have been deposited to the ProteomeXchange Consortium via the PRIDE ${ }^{66}$ partner repository with the dataset identifier PXD017509.

\section{Results \& Discussion}

\section{Transcriptome analysis}

The Sepia officinalis WB transcriptome comprised 155,614 transcript sequences including isoforms of 92,295 genes (according to the "gene" definition provided by Trinity assembler) with an average length of 609 nucleotides. Ninety-five percent of the global expression of the transcriptome corresponded to 22,208 transcripts, including a lot of slightly expressed transcripts. Based on the presence of a blastx hit against the uniprot-swissprot database, 19\% of all transcripts included in the WB transcriptome were annotated. KEGG annotation using the KAAS annotation tool led to the functional annotation of 21,779 predicted protein sequences representing 5,354 unique K numbers. The low level of annotation of the WB transcriptomes 
of Sepia officinalis and other cephalopods ${ }^{40,41}$ - around $20 \%$ - revealed a lot of unknown genes. Such a low level of annotation is commonly found in a special model like the cuttlefish Sepia officinalis, as already reported for the central nervous system (CNS) transcriptome with only $28 \%{ }^{59}$, accesory nidamental gland with $34 \%$ or posterior salivary glands (PSG) with $45 \%$. The higher level of annotated transcripts in the PSG causing neurotoxic saliva is explained by previous studies carried out on venoms of invertebrates and snakes.

Besides, 7 of the 10 most expressed transcripts were not annotated. These genes may possess relevant functions, highlighting the need for novel works on Cephalopod genomes. The 20 most expressed transcripts in cuttlefish included histone $\mathrm{H} 1$, hephaestin-like protein, ribosomal proteins, peptidoglycan recognition protein 2 (PGRP2), elongation factor $1-\alpha$, poly(rC)-binding protein 3, and tubulin $\alpha$ chain. Interestingly, 29,281 proteins were predicted by transdecoder, and 21,323 of them had a blastp hit against the uniprot-swissprot database, corresponding to an annotation level of $73 \%$.

\section{Proteome analysis}

To complete the WB transcriptome analysis, we conducted a double proteome analysis on the WB extract. First, separation on SDS-PAGE coupled with a fast MALDI-MS analysis was performed to provide an overview of the most abundant proteins in the WB extract. Secondly, separation by nanoLC coupled with ESI-MS analysis allowed us to access to a large number of proteins, including low abundant proteins in the WB proteome, but also to compare the WB and Hct proteomes.

MALDI-MS analysis allowed us to identify the most abundant proteins for each molecular weight (Figure 1, Table S1). We identified twenty-four proteins, ranging from 15 to $160 \mathrm{kDa}$, including enzymes, proteins associated to general stress (heat shock protein 90) or to oxidative 
stress (glutathione S-transferase, peroxiredoxin-1). The thioester-containing protein 1 (CD109), whose function remains unclear in Cephalopods, was also identified. Numerous cellularprocess-related proteins like proteins involved in the energy or calcium metabolisms (e.g., glyceraldehyde-3-phosphate dehydrogenase (G3PD), malate dehydrogenase or calmodulin) complete this analysis, along with translation factors (e.g. elongation factor 2), GTPase activators (e.g. Rab GDP dissociation inhibitor beta and Rho GDP-dissociation inhibitor 2), proteasome subunits (e.g. proteasome subunit $\alpha 2$-like and proteasome subunit $\alpha 1$-like) or actin and actin-related proteins (e.g. actin II, radixin and actophorin-like).

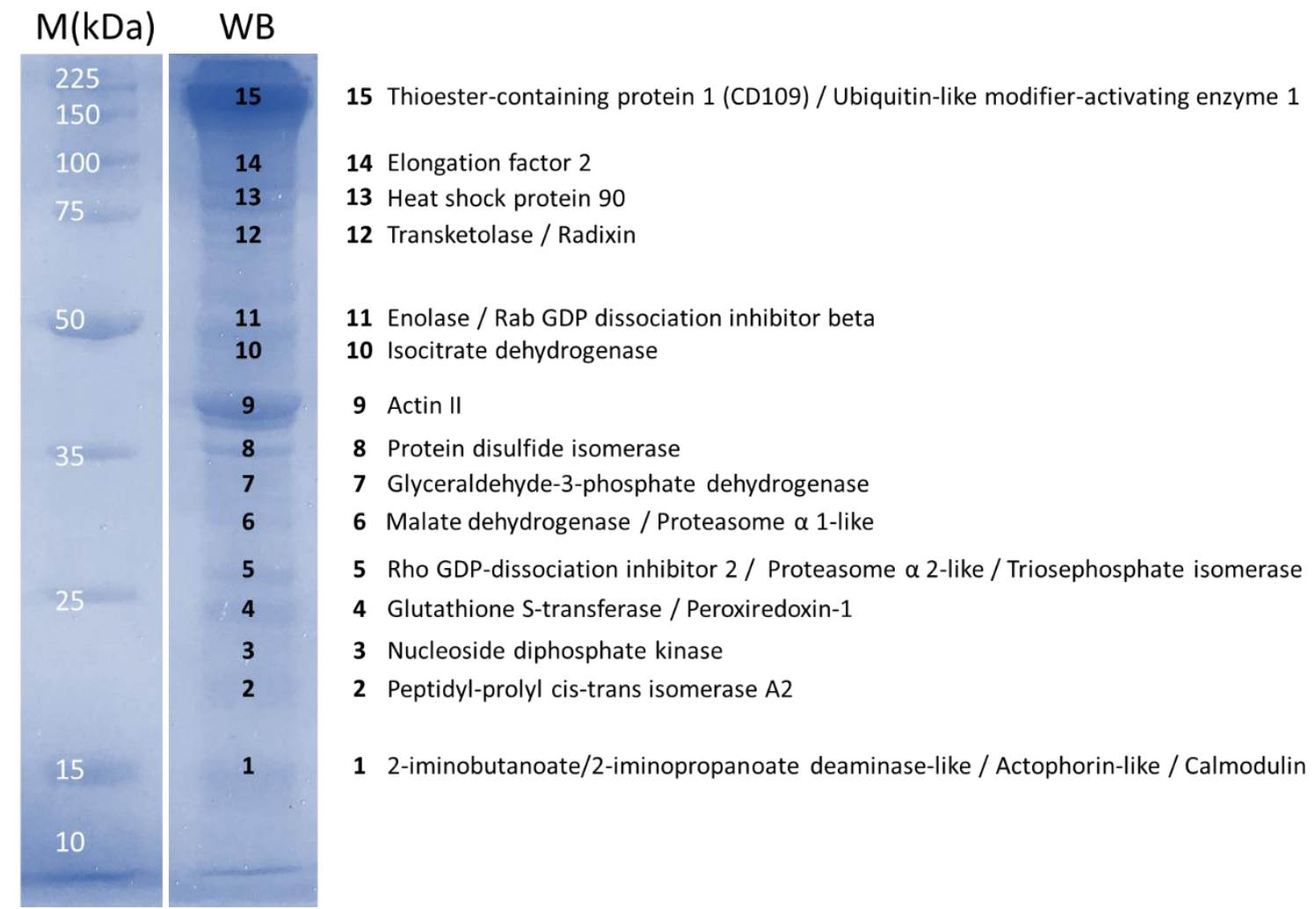

Figure 1. Proteomic analysis of Sepia officinalis white body extract. Gel lanes of white body extract (WB) and protein standard (M). Numbers represent gel slices subjected to trypsin digestion and MS/MS identification. The list of proteins identified by MALDI-TOF MS/MS from gel slices is represented on the side of the gel.

To study the WB proteome further and compare the WB and Hct proteomes, nanoLC ESIMS was performed in triplicate on WB and Hct extracts. Totals of 4,049 and 2,095 proteins 
were identified, respectively. A comparative study of the WB and Hct proteomes, illustrated by a Venn diagram (Figure 2), highlighted 1,870 proteins in common, 2,179 proteins specific to the WB extract, and 225 proteins specific to the Hct extract. Among the 10 most abundant proteins in the WB extract, five were also identified by fast MALDI-MS, i.e., G3P, calmodulin, Rho GDP dissociation inhibitor, nucleoside diphosphate kinase, and protein disulphide isomerase. Two of the ten most abundant proteins in the WB extract were in common with the Hct extract, namely nucleoside diphosphate kinase and COMM domain-containing protein 9 (COMD9). Besides, COMD9 was the most abundant protein in the Hct extract and the third most abundant protein in the WB extract. Among the other most abundant proteins in the Hct extract, three proteins involved in cell shape such as profilin-2, myosin regulatory light polypeptide and myosin-2 essential light chain were represented. Finally, 1 of the 10 most abundant proteins remained unknown in both extracts. 


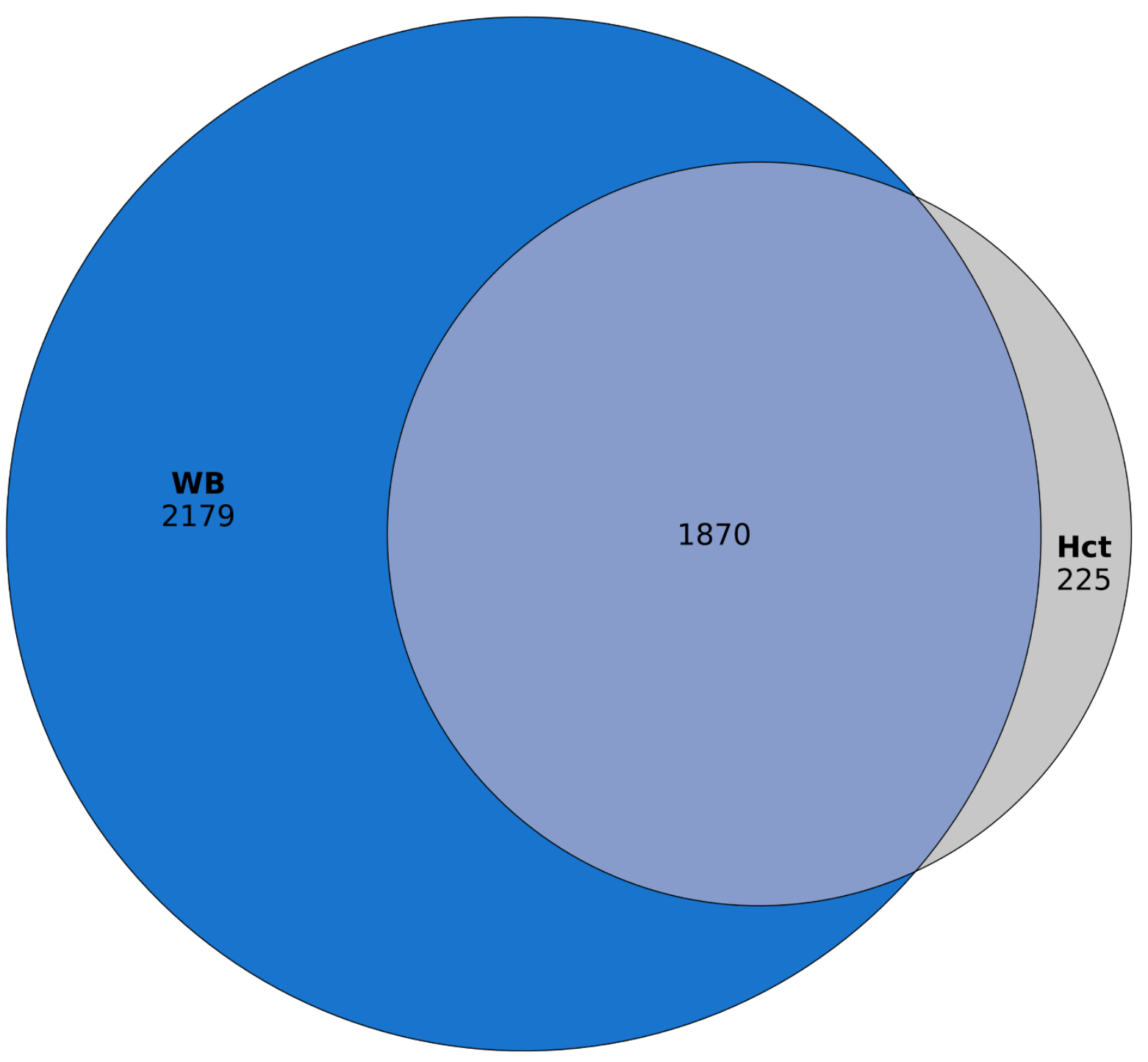

Figure 2. Venn diagram showing the distribution of proteins identified by Tims-TOF nanoLCMS in the white body (WB) only, haemocytes (Hct) only, and in both the white body and haemocytes.

KEGG annotation using the BlastKOALA annotation tool was performed to obtain a functional annotation of the proteins identified in the WB and Hct extracts. KEGG annotation of the WB proteome led to the functional annotation of 2,943 protein sequences representing 1,315 unique K numbers. KEGG annotation of the Hct proteome led to the annotation of 1,557 protein sequences representing 631 unique K numbers. Seventy-two and $74 \%$ of the protein 
sequences identified in the WB and Hct extracts were annotated, respectively, corresponding to the annotation level obtained by transdecoder with predicted proteins.

\section{The white body harbours intensive metabolic activity}

Table 1 represents the distribution of the KEGG annotations of the annotated transcripts of the WB transcriptome in relevant categories, representing $27 \%$ of all KEGG annotations obtained for the WB transcriptome.

Table 1. Distribution of functional annotations into relevant pathways of the WB transcriptome using the KEGG Orthology (KO) database.

\begin{tabular}{|c|c|c|c|}
\hline & ID pathways & Pathway description & $\begin{array}{c}\text { Number of matches } \\
\text { in gene list }\end{array}$ \\
\hline \multirow{5}{*}{$\begin{array}{l}\text { Cellular } \\
\text { processes }\end{array}$} & ko01100 & Metabolic pathways & 720 \\
\hline & ko03013 & RNA transport & 115 \\
\hline & ko03010 & Ribosome & 115 \\
\hline & ko04141 & $\begin{array}{l}\text { Protein processing in } \\
\text { endoplasmic reticulum }\end{array}$ & 107 \\
\hline & ko03022 & Basal transcription factors & 32 \\
\hline \multirow{3}{*}{$\begin{array}{l}\text { Cell } \\
\text { proliferation }\end{array}$} & ko04151 & PI3K-Akt signalling pathway & 100 \\
\hline & ko04010 & MAPK signalling pathway & 88 \\
\hline & ko04110 & Cell cycle & 81 \\
\hline \multirow{2}{*}{ Haematopoiesis } & ko04630 & JAK-STAT signalling pathway & 17 \\
\hline & ko04330 & Notch signalling pathway & 23 \\
\hline \multirow[b]{2}{*}{ Immunity } & ko04620 & NF- $\kappa \mathrm{B}$ signalling pathway & 34 \\
\hline & ko04064 & $\begin{array}{l}\text { Toll-like receptor signalling } \\
\text { pathway }\end{array}$ & 30 \\
\hline
\end{tabular}

The most represented category was metabolic pathways, with 720 matches (Table 1). Other cellular processes involved in transcription (RNA transport with 115 matches, basal transcription factors with 32 matches) and translation (ribosome with 115 matches, protein processing in endoplasmic reticulum with 107 matches) were also represented. In addition, elongation factor $1-\alpha$, tubulin $\alpha$ chain and ribosomal proteins were some of the most expressed transcripts. Both -omic approaches demonstrated that the WB had an intense metabolic activity 
partly associated to haematopoiesis. Indeed, 19 of the 24 proteins identified by fast MALDIMS analysis of WB extract (G3P dehydrogenase, malate dehydrogenase, triosephosphate dehydrogenase, or calmodulin) were found involved in metabolic processes. The proteome of PSG of the cuttlefish Sepia officinalis was established using the same MALDI-MS analysis ${ }^{65}$. Out of the 23 proteins identified in PSG extracts, most of them were toxins and toxic enzymes such as cephalotoxins, cystein-rich secreted protein (CRISP), peptidases S1, or phospholipases A2. Only 5 proteins were involved in metabolic processes, i.e. glyceraldehyde-3-phosphate dehydrogenase, chitinase, cytochrome c subunits (I and III) and ATP synthase beta subunit, whereas 19 out of 24 proteins identified in the WB were found involved in metabolic processes. Comparatively, the fast MALDI-MS analysis allowed us to see that the WB seems to possess a different metabolism than PSG in cuttlefish.

ESI-MS analysis of the WB proteome evidenced that 5 of the 10 most abundant proteins were involved in cellular processes such as energy, calcium or amino acid metabolism. Table 2 represents the distribution of the KEGG annotations of the proteins identified by ESI-MS analysis of WB extracts in relevant categories, representing $40 \%$ of all KEGG annotations obtained for the WB proteome. 
Table 2. Distribution of functional annotations into relevant pathways of the proteins identified by nanoLC ESI-MS in WB extracts, Hct extracts, or both, using the KEGG Orthology (KO) database.

\begin{tabular}{|c|c|c|c|c|c|}
\hline & $\begin{array}{c}\text { ID } \\
\text { pathways }\end{array}$ & Pathway description & $\begin{array}{c}\text { WB } \\
\text { extract }\end{array}$ & $\begin{array}{c}\text { Het } \\
\text { extract }\end{array}$ & Common \\
\hline \multirow{5}{*}{$\begin{array}{l}\text { Cellular } \\
\text { processess }\end{array}$} & ko01100 & Metabolic pathways & 241 & 117 & 116 \\
\hline & ko03010 & Ribosome & 74 & 27 & 27 \\
\hline & ko03013 & RNA transport & 52 & 15 & 15 \\
\hline & ko04141 & $\begin{array}{l}\text { Protein processing in endoplasmic } \\
\text { reticulum }\end{array}$ & 38 & 22 & 22 \\
\hline & ko03022 & Basal transcription factors & 6 & 0 & 0 \\
\hline \multirow{3}{*}{$\begin{array}{l}\text { Cell } \\
\text { proliferation }\end{array}$} & ko04151 & PI3K-AKT signalling pathway & 30 & 17 & 17 \\
\hline & ko04010 & MAPK signalling pathway & 35 & 18 & 18 \\
\hline & ko04110 & Cell cycle & 21 & 8 & 8 \\
\hline Haematopoiesis & ko04630 & JAK-STAT signalling pathway & 5 & 2 & 2 \\
\hline \multirow{2}{*}{ Immunity } & ko04620 & Toll-like receptor signalling pathway & 15 & 4 & 4 \\
\hline & ko04064 & NF-kappa B signalling pathway & 7 & 3 & 2 \\
\hline
\end{tabular}

Most of these proteins are involved in cellular processes such as metabolic pathways (241 matches), transcription (RNA transport with 52 matches, basal transcription factors with 6 matches) and translation (ribosome with 74 matches, protein processing in endoplasmic reticulum with 38 matches). Moreover, MAPK signalling, cell cycle and PI3K-AKT pathway members were identified by transcriptomic and proteomic analysis (Figures S1 - 3). In Mammals, the MAPK and PI3K-AKT pathways are involved in cell proliferation and the cell cycle $^{67-69}$. These two pathways may therefore play a role in the regulation of cell proliferation in the cuttlefish WB. Finally, DNA replication licensing factors mcm 2, 3, 4, 5, 6 and 7 were identified in the WB proteome as they were in Pacifastacus leniusculus haematopoietic lineages ${ }^{70}$, confirming the high proliferative rate of WB cells. 


\section{The white body is involved in haematopoiesis}

A comparative study of the WB and Hct proteomes (Figure 2) recovered 1,870 proteins in common. Proteins involved in the calcium metabolism or the regulation of $\mathrm{Ca}^{2+}$-dependent signalling pathways such as calreticulin, annexin A7 or calmodulin were identified in the cuttlefish WB and Hct proteomes as well as in the Hct proteomes of other Protostomes ${ }^{71-76}$. Two other proteins 14-3-3 proteins zeta and epsilon, previously identified in the Hct proteomes of Pomacea canaliculata ${ }^{71}$, Armadilidium vulgare ${ }^{73}$ and Penaeus monodon ${ }^{77}$ were identified in the WB and Hct proteomes of cuttlefish. Moreover, $90 \%$ of the Hct proteome was identified in the WB proteome (Figure 2), confirming the morphological observations of Claes $^{37}$ regarding the presence of Hct or Hct-like cells in the WB.

Transcriptomic analysis revealed the presence of eighteen haematopoiesis-related transcripts; they are reported in Table 3. The occurrence of WB proteins encoded by seven transcripts was confirmed by proteomic analysis (Table 4). 
Table 3. Haematopoiesis-related transcripts identified in Sepia officinalis white body extracts.

\begin{tabular}{|c|c|c|c|c|c|}
\hline Transcript & $\begin{array}{c}\text { TR } \\
\text { length } \\
\text { (bp) }\end{array}$ & $\begin{array}{c}\text { PR } \\
\text { length } \\
\text { (aa) }\end{array}$ & Name & Putative function & TPM \\
\hline DN18877_c5_g6_i1 & 1638 & 432 & $\begin{array}{l}\text { Receptor tyrosine-protein kinase erbB-4 } \\
\text { (erB4) }\end{array}$ & $\begin{array}{l}\text { Positive regulation of receptor } \\
\text { signalling pathway via JAK-STAT }\end{array}$ & 0.75 \\
\hline DN18468_c4_g1_i1 & 3015 & 891 & Janus kinase (JAK) & Phosphorylates STAT & 1.19 \\
\hline DN19189_c7_g1_i2 & 3248 & 757 & $\begin{array}{l}\text { Signal transducer and activator of } \\
\text { transcription-1 (STAT-1) }\end{array}$ & Transcription activation & 8.84 \\
\hline DN19938_c3_g1_i10 & 2260 & 696 & $\begin{array}{l}\text { Signal transducer and activator of } \\
\text { transcription-2 (STAT-2) }\end{array}$ & Transcription activation & 0.46 \\
\hline DN4958_c0_g1_i2 & 2127 & 489 & Suppressor of cytokine signalling-1 (SOCS-1) & STAT inhibition & 0 \\
\hline DN18015_c1_g1_i1 & 1374 & 319 & Suppressor of cytokine signalling-2 (SOCS-2) & STAT inhibition & 0.67 \\
\hline DN18952_c6_g1_i10 & 1991 & 554 & $\begin{array}{l}\text { Signal transducing adapter molecule } 1 \\
\text { (STAM-1) }\end{array}$ & $\begin{array}{l}\text { IL2 signal transduction - JAK } \\
\text { interaction }\end{array}$ & 0.029 \\
\hline DN18544_c1_g1_i4 & 2041 & 445 & STAM binding protein (AMSH) & $\begin{array}{l}\text { Zinc metalloprotease - STAM1 } \\
\text { binding }\end{array}$ & 2.11 \\
\hline DN6680_c0_g1_i1 & 821 & 140 & Transcriptional activator Myb (Myb) (partial) & Transcription activation & 0.24 \\
\hline DN19493_c9_g3_i1 & 1359 & 328 & $\begin{array}{l}\text { Fibroblast growth factor receptor (FGFR) } \\
\text { (partial) }\end{array}$ & FGFR signalling & 16.13 \\
\hline DN41498_c0_g1_i1 & 793 & 156 & Myeloid leukemia factor (MLF) (partial) & Enhances myeloid formation & 0.48 \\
\hline DN18311_c4_g1_i1 & 2971 & 830 & $\begin{array}{l}\text { Cleavage and polyadenylation specificity } \\
\text { factor subunit } 1 \text { (CPSF-1) (partial) }\end{array}$ & mRNA polyadenylation & 19.15 \\
\hline DN16050_c0_g1_i1 & 4427 & 1407 & Thioester-containing protein 1 (CD109) & Endopeptidase inhibitor & 5.25 \\
\hline DN18752_c1_g2_i1 & 1750 & 396 & E3 ubiquitin-protein transferase MAEA (Emp) & Erythroblast maturation & 14.01 \\
\hline DN4830_c0_g1_i1 & 1111 & 114 & Macrophage migration inhibitory factor (MIF) & Haemocyte activation & 26.21 \\
\hline DN18927_c3_g1_i11 & 1460 & 429 & Interleukin enhancer-binding factor 2 (NF45) & $\begin{array}{l}\text { Regulation of transcription - } \\
\text { Proliferation }\end{array}$ & 415.06 \\
\hline DN18551_c3_g1_i3 & 1097 & 179 & Myeloid-derived growth factor (MYDGF) & $\begin{array}{l}\text { Endothelial cell } \\
\text { proliferation/angiogenesis }\end{array}$ & 16.76 \\
\hline DN19181_c2_g4_i4 & 2228 & 434 & GATA-binding factor 3 (GATA3) & $\begin{array}{l}\text { Transcription activation - } \\
\text { Differentiation }\end{array}$ & $\begin{array}{l}8.52 \mathrm{e}- \\
05\end{array}$ \\
\hline DN15952_c0_g1_i1 & 1728 & 452 & Cytokine receptor-like factor 3 (p48) & $\begin{array}{l}\text { Regulation of cell cycle - } \\
\text { Differentiation }\end{array}$ & 38.84 \\
\hline
\end{tabular}

TR: transcript, bp: base pair, PR: protein, aa: amino acid, TPM: transcript per million 
Table 4. Proteins identified by nanoLC-MS/MS in Sepia officinalis white body and haemocyte extracts.

\begin{tabular}{|c|c|c|c|c|c|c|c|c|c|c|c|}
\hline & & & & & WB & extract & & & Het & extract & \\
\hline & 1 & Transcript & ) & Score & \#Pep & $\begin{array}{c}\% \\
\text { Cover }\end{array}$ & iBAQ & Score & \#Pep & $\begin{array}{c}\% \\
\text { Cover }\end{array}$ & iBAQ \\
\hline & STAT-1 & DN19189_c7_g1_i2 & 88 & 133.37 & 10 & 19.42 & .48 & ND & $\mathrm{ND}$ & ND & ND \\
\hline & STAM1 & DN18952_c6_g1_i10 & 60 & 160.26 & 11 & 25.63 & 204.51 & 51.24 & 2 & 6.32 & 22.28 \\
\hline . & AMSH & DN18544_c1_g1_i4 & 50 & 116.18 & 8 & 22.7 & 53.81 & 101.73 & 5 & 12.13 & 31.80 \\
\hline 气̊ํㄹ & CD109 & DN16050_c0_g1_i1 & 158 & 429.21 & 296 & 63.8 & 7947.57 & 396.48 & 193 & 53.34 & 4465.78 \\
\hline ⿷匚ّ & MYDGF & DN18551_c3_g1_i3 & 21 & 71.93 & 2 & 8.38 & 130.75 & 43.21 & 2 & 8.38 & 32.91 \\
\hline & NF45 & DN18927_c3_g1_i11 & 47 & 231.89 & 36 & 51.75 & 2298.56 & 145.56 & 8 & 13.05 & 449.17 \\
\hline & $\mathrm{p} 48$ & DN15952_c0_g1_i1 & 50 & 190.35 & 15 & 55.97 & 480.16 & ND & $\mathrm{ND}$ & ND & ND \\
\hline & Tollip & DN18451_c8_g2_i2 & 25 & 88.07 & 2 & 13.06 & 206.45 & NI & NI & NI & 20.52 \\
\hline & IRAK4 & DN17586_c2_g4_i1 & 35 & 106.79 & 5 & 17.19 & 110.49 & ND & ND & ND & ND \\
\hline 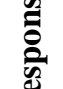 & $\begin{array}{c}\text { NF-кB } \\
\text { p105 }\end{array}$ & DN17588_c10_g1_i11 & 62 & 99.58 & 3 & 9.65 & 73.84 & ND & $\mathrm{ND}$ & ND & ND \\
\hline$\stackrel{0}{g}$ & PGRP-2 & DN19986_c8_g1_i3 & 30 & 91.75 & 3 & 11.41 & 10.07 & $10 \pi$ & 101 & NI & 17.94 \\
\hline E & Galectin-1 & DN16917_c6_g1_i2 & 63 & 110.3 & 6 & 16.09 & 112.36 & NI & NI & NI & 7.13 \\
\hline & Mx1 & DN18954_c2_g1_i6 & 81 & 186.94 & 27 & 27.77 & 550.57 & ND & $\mathrm{ND}$ & ND & ND \\
\hline & $\begin{array}{l}\text { DMBT1 } \\
\text { (partial) }\end{array}$ & DN19666_c3_g1_i2 & NA & 44.1 & 3 & 13.02 & 30.14 & ND & $\mathrm{ND}$ & ND & ND \\
\hline & $\mathrm{SOD} \mathrm{Cu/Zn}$ & DN191 & 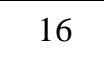 & 181.34 & 13 & 92 & & 94.87 & 6 & 90.67 & 887.3 \\
\hline & SOD Mn & DN19447_c0_g1_i1 & 26 & 86.09 & 2 & 17.87 & & ND & $\mathrm{ND}$ & ND & ND \\
\hline & PRX1 & DN12991_c0_g1_i1 & 28 & 281.46 & 53 & 90.44 & 6111.43 & 140.54 & 13 & 58.57 & 426.38 \\
\hline & PRX4 & DN11617_c0_g1_i1 & 29 & 55.88 & 2 & 10.08 & 12.40 & ND & $\mathrm{ND}$ & ND & ND \\
\hline$\overline{0}$ & PRX5 & DN16455_c1_g1_i3 & 21 & 169.02 & 18 & 59.47 & 149.47 & 162.07 & 18 & 59.47 & 1080.04 \\
\hline 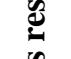 & PRX6 & DN16601_c0_g1_i2 & 29 & 258.91 & 82 & 81.64 & 3792.89 & 224.28 & 60 & 79.69 & 4802.00 \\
\hline$=$ & GST & DN17393_c4_g1_i4 & 25 & 225.04 & 40 & 84.33 & 4687.56 & 149.18 & 14 & 52.07 & 770.67 \\
\hline & HSP70 & DN19855_c3_g3_i1 & 96 & 271.28 & 48 & 61.16 & 767.97 & 144.1 & 9 & 15.11 & 42.98 \\
\hline & HSC71 & DN19063_c5_g1_i1 & 71 & 319.81 & 102 & 69.34 & 1329.63 & 255.69 & 50 & 52.85 & 161.13 \\
\hline & HSP78 & DN17831_c5_g2_i1 & 74 & 287.58 & 70 & 61.3 & 2876.24 & 274.07 & 50 & 55.87 & 1417.87 \\
\hline & HSP90 & DN18504_c4_g1_i2 & 83 & 363.47 & 191 & 81.83 & 10588.07 & 290.16 & 73 & 64.91 & 1252.74 \\
\hline
\end{tabular}

Score: - $\log 10$ P-value, NA: non available, ND: not detected, NI : not identified, \#Pep: peptides number, iBAQ: Intensity Based Absolute Quantification.

KEGG annotation of the WB transcriptome (Table 1) and proteome (Table 2), retrieved 17 transcripts and 5 proteins related to the JAK-STAT pathway (Figure 3). 


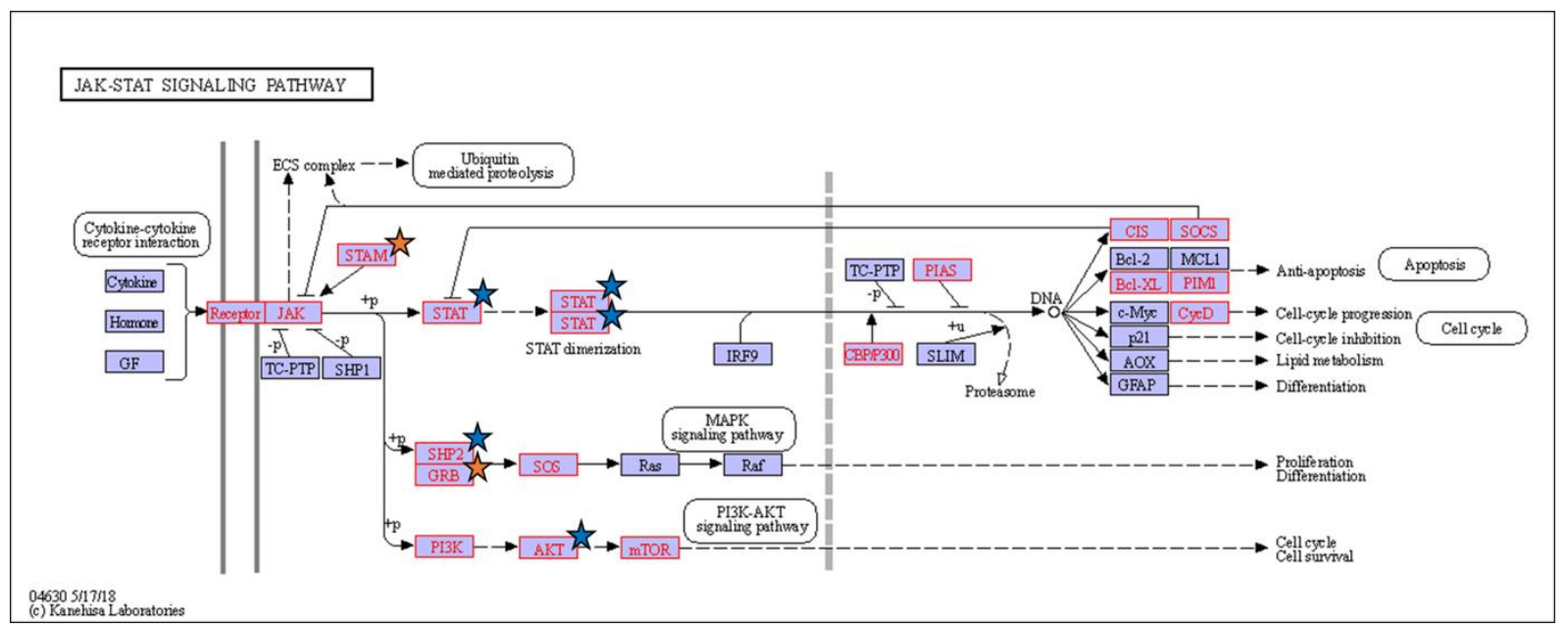

Figure 3. JAK-STAT signalling pathway. Red boxes represent proteins identified in the WB transcriptome, blue stars represent proteins identified in the WB proteome, and orange stars represent proteins identified in both the WB and Hct proteomes.

These JAK-STAT pathway members were aligned with human (Homo sapiens) and mouse (Mus musculus) homologues. So-JAK possessed 27\% homology with both human (O60674.2) and mouse (Q62120.2) JAK2. So-STAT-1 and So-STAT-2 possessed 39\% and 27\% homology with human (P51692.2) and mouse (P42232.1) STAT5B, respectively. So-STAT-1, the most expressed member of the canonical JAK-STAT pathway in the transcriptomic analysis, was detected in the WB protein extract, suggesting a correlation between transcription and protein abundance. So-SOCS-1 and So-SOCS-2 possessed 52\% and 51\% homology with human (O14512.2) and mouse (Q8VHQ2.1) SOCS7, respectively. Annotation of protein domains revealed that So-STAT-1, So-STAT-2, So-SOCS-1 and So-SOCS-2 possessed the Src homology 2 (SH2) domain, while So-JAK lacked this domain. So-JAK possessed the protein kinase domain and the catalytic domain of protein kinase (TyrKc domain) also found in mammal homologues. So-STAT-1 and So-STAT-2 possessed the STAT protein interaction domain (STAT int), the STAT DNA-binding domain (STAT bind) and the STAT alpha domain. So-SOCS1 and So-SOCS-2, like their mammal homologues, possessed the SOCS box domain. 
The JAK-STAT pathway is involved in haematopoiesis in Vertebrates, with four JAKs and seven STATs identified in Mammals ${ }^{42,43}$. It is also found in one Protostome, Drosophila melanogaster, with one JAK, called Hopscotch $(\mathrm{HOP})^{78}$, and one STAT, called STAT92E ${ }^{79,80}$. In Drosophila melanogaster, JAK is coupled with a transmembrane receptor named Domeless $(\mathrm{DOME})^{81,82}$, which is activated by three ligands: Unpaired (UPD), UPD2, and UPD3 ${ }^{83-86}$. In Mammals, numerous cytokine receptors are involved in the activation of the JAK-STAT pathway ${ }^{45}$. In Sepia officinalis, no definitive receptor or ligand related to the JAK-STAT pathway has been identified. Nevertheless, a receptor tyrosine-protein kinase erbB-4 homologue involved in the regulation of JAK-STAT signalling in humans was identified in cuttlefish $^{87}$. Considering the low level of annotation, unknown genes may also be involved in JAK-STAT activation but may have slipped through our search, proving the need for further studies. However, a Janus kinase was identified for the first time in a cephalopod species. Moreover, a STAT homologue was identified for the first time in a protein extract from a molluscan species. These results reinforce the involvement of JAK-STAT signalling in the regulation of haematopoiesis in all animal species.

Nineteen members of the Notch signalling pathway including Notch, Fringe, Delta Deltex, as well as co-activators and co-suppressors of the pathway, were identified in the WB transcriptome by KEGG annotation. Three proteins (Notch, Deltex and HDAC) were detected by proteomic approach in cuttlefish WB (Figure S4). The Notch signalling pathway is involved in haematopoiesis in Drosophila ${ }^{88}$ and Mammals ${ }^{89,90}$, suggesting that this pathway is involved in haematopoiesis in cuttlefish.

Other annotated transcripts corresponding to potential markers of haematopoietic cells well described in Mammals were identified in cuttlefish WB, e.g., the myeloid leukaemia factor (MLF), the E3 ubiquitin-protein transferase (MAEA), the erythroblast macrophage protein (Emp) or the thioester-containing protein 1 (CD109) (Table 4). In human, MLF is expressed in 
CD34+ haematopoietic progenitor cells of the bone marrow and plays a role in the early stage of haematopoiesis ${ }^{91}$; it may also contribute to the maintenance of haematopoietic stem cells $(\mathrm{HSC})^{92}$. Emp mediates erythroblast-macrophage interactions and the terminal maturation and enucleation of erythroid cells in vitro ${ }^{93}$, and its expression suggests a function in bone marrow haematopoiesis ${ }^{94}$. CD109 identified in cuttlefish, a member of the thioester-containing protein family, possesses sequence identity levels of 30.06\% with human CD109 (Q6YHK3.2) and $58.87 \%$ with Euprymna scolopes thioester-containing protein (AFV94409.1), and differs from the a2-macroglobulin previously identified in PSG extracts ${ }^{65}$. In human, CD109 is expressed by $\mathrm{CD} 34+$ cells $^{95,96}$ and during neutrophil and monocyte maturation ${ }^{97}$, making it a putative marker of HSC. A CD109 transcript is also present in Euprymna tasmanica $\mathrm{WB}^{40}$, suggesting a putative role in Hct production in Cephalopods. However, CD109 is involved in immune processes like those described in human T-cells ${ }^{98}$ or in Euprymna scolopes ${ }^{99}$. The expression of Es-CD109 is down-regulated in the light organ of symbiotic juveniles as compared to aposymbiotic juveniles, suggesting that the cephalopod immune system is modulated in the presence of bacterial symbionts in the light $\operatorname{organ}^{99}$. The identification of these homologs of haematopoiesis markers in the cuttlefish WB confirms the presence of HSC in the WB, previously morphologically described and called "haemocytoblast" by Claes ${ }^{37}$.

Two transcription factors, one partial sequence of the transcriptional activator Myb (Myb), and GATA-binding factor 3 (GATA3) were identified in cuttlefish. Myb is a major regulator of haematopoiesis in mouse and is involved in red blood cell and $\mathrm{T}$ cell development ${ }^{100,101}$. Moreover, Myb mutation induces a decrease in the number of red blood cells, B cells and T cells, and an increase in haematopoietic cells ${ }^{102}$. In cuttlefish, Myb may be a regulator of Gata3, as described in mouse ${ }^{103}$. Gata3 was found mainly expressed in the gills of Crassostrea gigas ${ }^{34}$ and up-regulated in gills during secondary challenge with Vibrio splendidus ${ }^{33}$. So-GATA3 has 
the DNA-binding domain YxKxHxxxRP described by Shinnakasu and collaborators ${ }^{104}$ (Figure 4). In cuttlefish, it may be involved in Hct production and regulated by Myb.

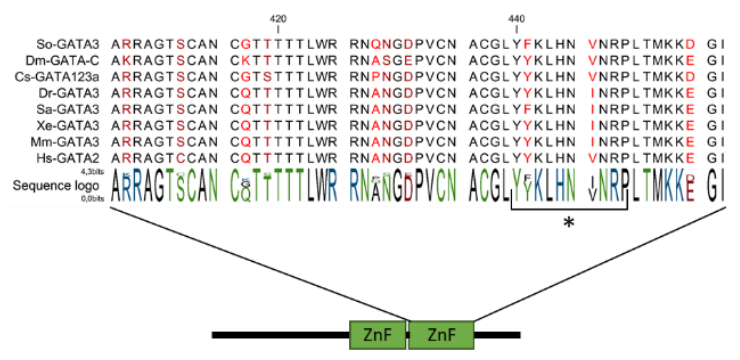

Figure 4. Sequence alignment of GATA transcription factors from various species. So-GATA3: GATA-binding factor 3 (Sepia officinalis), Dm-GATA-C: GATA-binding factor C, P91623.1 (Drosophila melanogaster), Cs-GATA123a: GATA transcription factor 123a, ADC35037.1 (Chaetopterus sp.), Dr-GATA3: Transcription factor GATA-3, Q91428.1 (Danio rerio), SaGATA3: Partial transcription factor GATA-3, AMD33522.1 (Sparus aurata), Xe-GATA3: GATA-binding factor 3, P23773.1 (Xenopus laevis), Mm-GATA3: Trans-acting T-cell-specific transcription factor GATA-3, P23772.1 (Mus musculus), Hs-GATA2: Endothelial transcription factor GATA-2, P23769.3 (Homo sapiens). Asterisk: DNA-binding domain. ZnF_GATA: zinc finger binding to DNA consensus sequence.

Two proliferation factors - interleukin enhancer-binding factor 2 (NF45) and the myeloidderived growth factor (MYDGF) - were identified in cuttlefish. In human, MYDGF promotes endothelial cell proliferation in vitro ${ }^{105}$, while NF45 binds to NF90 and stimulates the regulation of gene expression ${ }^{106}$. Disruption of both NF90 and NF45 impaired endothelial stem cell proliferation, suggesting that NF45 and NF90 are involved in the regulation of cell proliferation ${ }^{107}$. A mammalian negative regulator of the cell cycle cytokine receptor-like factor $3(\mathrm{p} 48)^{108}$ was identified in cuttlefish, where it may be involved in Hct proliferation and differentiation with MYDGF and NF45. These factors may be involved in haemocyte proliferation and differentiation in cuttlefish WB and in the maturation process previously 
proposed by Claes $^{37}$. Moreover, a cytokine macrophage migration inhibitory factor (MIF) was identified in cuttlefish, as described in two other molluscs ${ }^{29,30}$. In B. glabrata, knock down of the MIF gene induced a decrease in the number of Hct, suggesting that it is involved in Hct activation $^{29}$. The cuttlefish MIF homologue may be involved in Hct production and activation. Finally, signal-transducing adapter molecule 1 (STAM-1) and the STAM-binding protein (or AMSH) were identified in WB protein extracts (Table 4). These two proteins are involved in signal transduction mediated by IL-2 ${ }^{109-111}$, while IL-2 is involved in HSC maintenance and normal haematopoiesis in mice ${ }^{112}$. Two other factors putatively involved in haematopoiesis and described in the transcriptome of the Euprymna tasmanica WB were identified in Sepia officinalis, i.e., partial sequences of subunit 1 of the cleavage and polyadenylation specificity factor (CPFS1) and of the fibroblast growth factor receptor (FGFR $)^{40}$. Disruption of the CPFS1 gene induced defective polyadenylation of snrnp70, a splicing factor required for HSC development in Danio rerio ${ }^{113}$. FGFR2 is the receptor of fibroblast growth factor 2, which is involved in haematopoiesis by enhancing HSC numbers ${ }^{114}$. This way, these factors could be involved in HSC maintenance in Sepia officinalis.

In addition to the annotation-based search on the WB transcriptome, a manual search for additional factors like Invertebrate drivers or putative previously identified drivers of haematopoiesis such as astakines from Pacifastacus leniusculus ${ }^{26,27}$ or Tal-1/Scl from Crassostrea gigas ${ }^{36}$ was performed, but did not yield relevant results.

\section{Involvement of the white body in immunity and the stress response}

In addition to haematopoiesis-related transcripts, several immune-related transcripts were identified in cuttlefish WB (Table 5), as previously reported in other cephalopods ${ }^{40,41}$. KEGG annotation of the WB transcriptome and proteome revealed the presence of 30 and 15 factors 
involved in the Toll-like receptor signalling pathway, respectively (Figure 5), and 34 and 7

factors involved in the NF-kB signalling pathway (Figure S5).

Table 5. Immune-related transcripts identified in Sepia officinalis white body extracts.

\begin{tabular}{|c|c|c|c|c|c|}
\hline Transcript & $\begin{array}{c}\text { TR } \\
\text { length } \\
\text { (bp) }\end{array}$ & $\begin{array}{c}\text { PR } \\
\text { length } \\
\text { (aa) }\end{array}$ & Name & Putative function & TPM \\
\hline DN12467_c0_g1_i1 & 2823 & 833 & Toll-like receptor $\gamma($ TLR $\gamma)$ & Toll signalling & 1.54 \\
\hline DN18158_c7_g2_i3 & 1385 & 338 & Myeloid differentiation factor 88 (MyD88) & Toll signalling & 15.98 \\
\hline DN18451_c8_g2_i2 & 955 & 222 & Toll-interacting protein (Tollip) & Toll signalling & 0 \\
\hline DN17586_c2_g4_i1 & 1111 & 319 & Interleukin-1-receptor-associated kinase-4 (IRAK-4) & $\mathrm{NF}-\kappa \mathrm{B}$ signalling & 0 \\
\hline DN17182_c1_g3_i2 & 2158 & 649 & Interleukin-1-receptor-associated kinase-1 (IRAK-1) & $\mathrm{NF}-\kappa \mathrm{B}$ signalling & 20.45 \\
\hline DN10923_c0_g2_i1 & 1821 & 498 & TNF receptor-associated factor 3 (TRAF3) & NF- $\mathrm{kB}$ signalling & 0.77 \\
\hline DN15884_c0_g1_i1 & 2990 & 703 & E3 ubiquitin-protein ligase TRAF7 (TRAF7) & $\mathrm{NF}-\kappa \mathrm{B}$ signalling & 2.65 \\
\hline DN19803_c7_g1_i3 & 2661 & 644 & $\begin{array}{l}\text { Inhibitor of nuclear factor } \kappa-B \text { kinase subunit } \alpha \\
(\mathrm{IKK} \alpha)\end{array}$ & $\mathrm{NF}-\mathrm{\kappa B}$ signalling & 0 \\
\hline DN17661_c4_g2_i1 & 2680 & 746 & $\begin{array}{l}\text { Inhibitor of nuclear factor } \kappa-B \text { kinase subunit } \varepsilon \\
(\mathrm{IKK} \varepsilon)\end{array}$ & $\mathrm{NF}-\mathrm{\kappa B}$ signalling & 6.86 \\
\hline DN16830_c5_g1_i2 & 2278 & 337 & NF- $\kappa B$ inhibitor $\alpha(\mathrm{I} \kappa \mathrm{B} \alpha)$ & $\mathrm{NF}-\kappa \mathrm{B}$ signalling & 10.24 \\
\hline DN17588_c10_g1_i11 & 3391 & 546 & 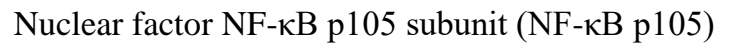 & $\mathrm{NF}-\kappa \mathrm{B}$ signalling & 0.35 \\
\hline DN25378_c0_g1_i1 & 915 & 187 & Calcineurin subunit B type $1(\mathrm{CnB})$ & Multifunctional protein & 2.48 \\
\hline DN18721_c3_g1_i1 & 2066 & 537 & Bactericidal/permeability-increasing protein (BPI) & Bacteria binding & 6.51 \\
\hline DN17974_c6_g1_i14 & 1146 & 271 & Peptidoglycan recognition protein 1 (PGRP-1) & Bacteria recognition & 15.11 \\
\hline DN19986_c8_g1_i3 & 1209 & 263 & Peptidoglycan recognition protein 2 (PGRP-2) & Bacteria recognition & 3512.24 \\
\hline DN16917_c6_g1_i2 & 2631 & 547 & Galectin-1 & Glucan recognition & 52.79 \\
\hline DN18092_c4_g1_i1 & 1280 & 310 & Galectin-2 & Glucan recognition & 1.24 \\
\hline DN18954_c2_g1_i6 & 2561 & 695 & Interferon-induced GTP-binding protein Mx1 (Mx1) & Antiviral activity & 4.53 \\
\hline DN19666_c3_g1_i2 & 2145 & 624 & $\begin{array}{l}\text { Deleted in malignant brain tumor } 1 \text { (partial) } \\
\text { (DMBT1) }\end{array}$ & Bacteria binding & 9.29 \\
\hline DN3551_c0_g1_i1 & 1716 & 408 & Laccase domain-containing protein & Oxidation & 0.69 \\
\hline DN19183_c4_g1_i1 & 407 & 153 & Superoxide dismutase $\mathrm{Cu} / \mathrm{Zn}(\mathrm{SOD} \mathrm{Cu} / \mathrm{Zn})$ & Oxidative stress protection & 217.35 \\
\hline DN19447_c0_g1_i1 & 1076 & 235 & Superoxide dismutase Mn (SOD Mn) & Oxidative stress protection & 91.71 \\
\hline DN12991_c0_g1_i1 & 1292 & 251 & Peroxiredoxin 1 (PRX1) & Oxidative stress protection & 17.23 \\
\hline DN12443_c0_g1_i1 & 936 & 250 & Peroxiredoxin 2 (PRX2) & Oxidative stress protection & 16.29 \\
\hline DN11617_c0_g1_i1 & 842 & 245 & Peroxiredoxin 4 (PRX4) & Oxidative stress protection & 111.41 \\
\hline DN16455_c1_g1_i3 & 1044 & 190 & Peroxiredoxin 5 (PRX5) & Oxidative stress protection & 103.37 \\
\hline DN16601_c0_g1_i2 & 1072 & 256 & Peroxiredoxin 6 (PRX6) & Oxidative stress protection & 822.45 \\
\hline DN17393_c4_g1_i4 & 784 & 217 & Glutathione S-transferase (GST) & Cellular detoxification & 1353.19 \\
\hline DN19855_c3_g3_i1 & 3837 & 847 & Heat shock protein 70 (HSP70) & Stress response & 15.95 \\
\hline DN19063_c5_g1_i1 & 3248 & 649 & Heat shock cognate 71 (HSC71) & Stress response & 85.79 \\
\hline DN17831_c5_g2_i1 & 2822 & 664 & Heat shock protein 78 (HSP78) & Stress response & 12.51 \\
\hline DN18504_c4_g1_i2 & 2684 & 721 & Heat shock protein 90 (HSP90) & Stress response & 71.39 \\
\hline
\end{tabular}

TR: transcript, bp: base pair, PR: protein, aa: amino acid, TPM: transcript per million 
Among the members of the Toll/NF- $\kappa \mathrm{B}$ pathway, we identified the following factors: one Toll-Like Receptor (So-TLR $\gamma$ ), Toll-interacting protein (Tollip), myeloid differentiation factor 88 (MyD88), interleukin-1-receptor associated kinases (IRAK-1 and -4), TNF receptorassociated factor 3 (TRAF3), and the E3 ubiquitin-protein ligase TRAF7 (TRAF7). Two subunits of the inhibitor of the nuclear factor kappa-B kinase (IKK $\alpha$ and IKKe), the NF- $\kappa B$ inhibitor $\alpha(\mathrm{I} \kappa \mathrm{B} \alpha)$, and the nuclear factor NF- $\kappa \mathrm{B}$ p100 subunit were also identified.

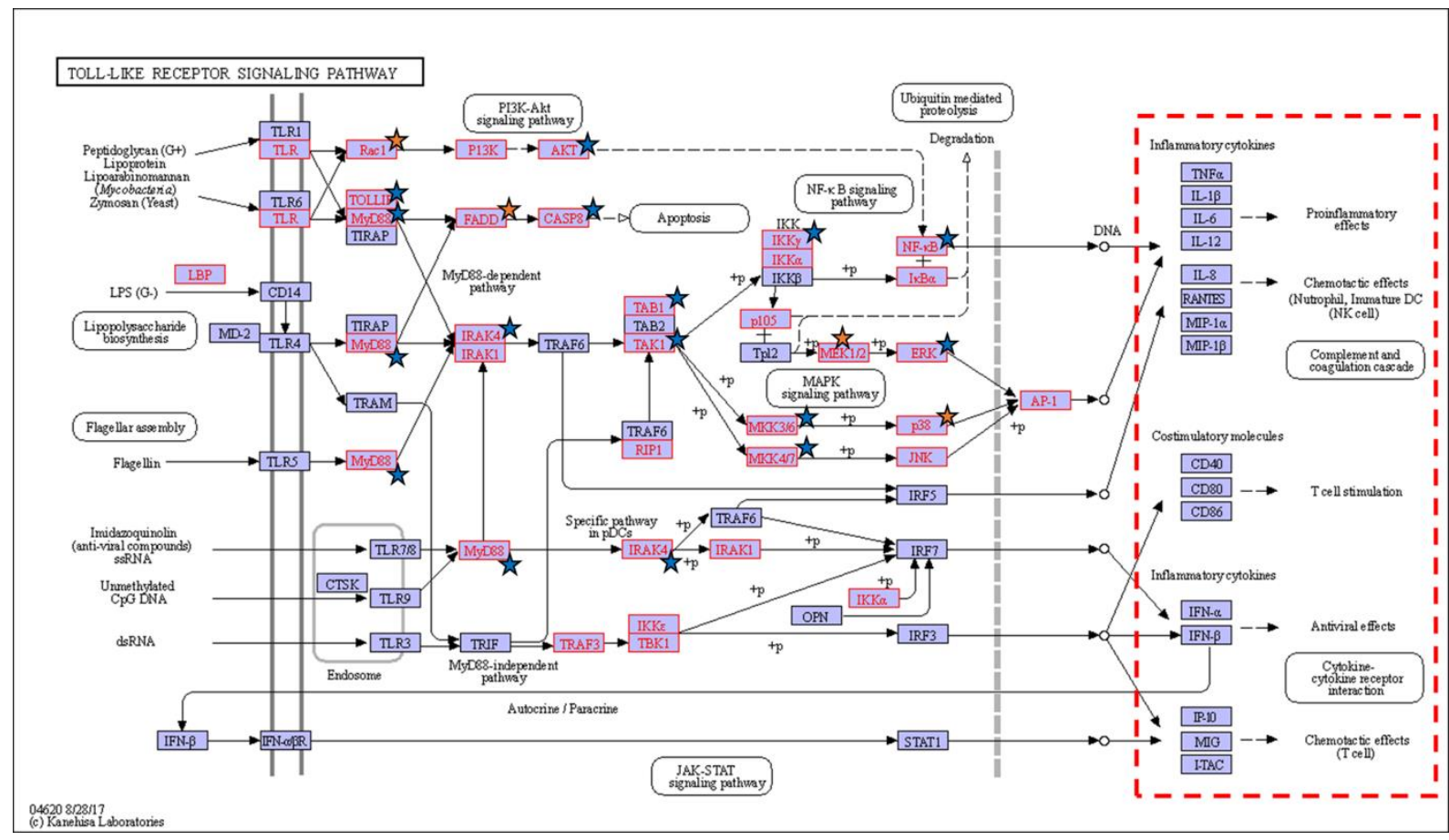

Figure 5. Toll-like receptor signalling pathway. Red boxes represent proteins identified in the WB transcriptome, blue stars represent proteins identified in the WB proteome, and orange stars represent proteins identified in both the WB and Hct proteomes.

Members of the Toll/NF-kB pathway are present in bilaterian species ${ }^{115-117}$, including

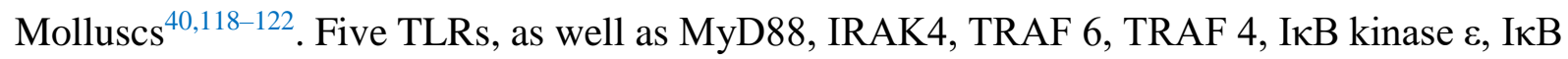
kinase $\gamma$, inhibitor of NF- $\kappa \mathrm{B}$ and REL/NF- $\kappa \mathrm{B}$ can be found in cuttlefish accessory nidamental gland $(\mathrm{ANG})^{120}$. By contrast, only one TLR was identified in the WB. So-TLR $\gamma$, previously identified in $\mathrm{ANG}^{120}$ contains one signal peptide, eleven LRRs (leucine rich repeats), one transmembrane domain, and the TIR (Toll interleukin-1 resistance) domain. So-TLR $\gamma$ possesses 
$31 \%$ identity with TLR4 of the oyster Pinctada imbricata, whose expression was significantly up-regulated $6 \mathrm{~h}$ after LPS injection ${ }^{123}$. So-MyD88 (myeloid differentiation factor 88), previously identified in $\mathrm{ANG}^{120}$, possesses both Death and TIR domains, and displays 97\% sequence identity with Sepiella japonica MyD88, another cephalopod MyD88 significatively up-regulated in the liver $24 \mathrm{~h}$ after LPS injection ${ }^{124}$. So-Tollip was identified in the WB proteome (Table 4); it possesses 68\% sequence identity with Mizuhopecten yessoensis Tollip, which was up-regulated after bacterial challenge ${ }^{125}$. So-Tollip may be involved in TLR4 signalling in cuttlefish, as described in human cells ${ }^{126}$. Finally, NF-kB p105 subunit was identified in both the WB transcriptome and proteome; it possesses the Rel homology domain (RHD), involved in DNA binding. So-NF-kB p105 subunit possesses $48 \%$ homology with human NF- $\kappa \mathrm{B}$ p105 subunit. NF- $\kappa \mathrm{B}$ p105 subunit is part of the Rel/NF- $\kappa \mathrm{B}$ transcription factor involved in the activation of immune genes in both vertebrate and invertebrate species ${ }^{127}$. Finally, as represented by the dotted rectangle in Figure 5, all the effectors of the TLR signalling pathway, including inflammatory cytokines and homologues of costimulatory molecules, were not found in the cuttlefish WB transcriptome. As previously discussed, these effectors may have slipped through annotation, confirming the need for further analyses.

In addition to members and regulators of the Toll/NF- $\kappa \mathrm{B}$ signalling pathway, other immune factors were identified in the cuttlefish WB transcriptome (Table 5), and the occurrence of several proteins was confirmed by proteomic approach only in WB extract (Table 4). The absence of identification of immune response proteins in the Hct extract could be explained by their low abundance in this sample. Using the "match between run" algorithm in PeaksX to compare Hct analyses with WB analyses, we detected 3 of these immune response proteins (tollip, PGRP-2 and galectin-1) in the Hct extract. By comparing several runs, this algorithm can detect peptides with identical $\mathrm{m} / \mathrm{z}$, retention times and ionic mobility even if MS/MS results are unexploitable because the intensity of the signal is too low. As showed in 
Table 4, the signal for these three proteins was much lower in the Hct extract, so that MS/MS results were unexploitable for identification. These different signals/abundances may reflect the different amounts of biological material available in an organ or tissue for the WB vs. in isolated cells for Hct, as illustrated by the SDS-PAGE gel (Figure S6).

Among proteins associated to immunity, we identified in WB transcriptome Calcineurin subunit $\mathrm{B}(\mathrm{CnB})$, which possesses 4 EF-hand domains involved in $\mathrm{Ca}^{2+}$ binding. The $\mathrm{Ca}^{2+}-$ dependent $\mathrm{CnB}$ is involved in the innate immune response in Drosophila larvae ${ }^{128}$ or Chinese mitten $\mathrm{crab}^{129}$. So-CnB possesses $96 \%$ homology with the oyster Pinctada fucata $\mathrm{CnB}$, which mediates the immune response of haemocytes through activation of NF- $\mathrm{B}^{130}$. Besides, So-CnB possesses $91 \%$ homology with human $\mathrm{CnB}$, where it may act in vivo as an immune response regulator via regulation of NF- $\kappa \mathrm{B}^{131}$. Finally, calcineurin-B homologous protein (CHP), which possesses $69 \%$ homology with mouse CHP, was also identified in the WB transcriptome. In mouse cells, CHP inhibits $\mathrm{CnB}^{132}$. This way, So-CHP may mediate So-CnB action in the regulation of the cuttlefish immune system. We cannot rule out a role of other $\mathrm{Ca}^{2+}$ binding proteins like $S o$-calreticulin or So-calmodulin in the immune response either, as described for calreticulin identified in the sea urchin (Heliocidaris erythogramma) ${ }^{133}$ or for calmodulin in Chinese mitten crab (Eriocheir sinensis) ${ }^{134}$.

The interferon-induced GTP-binding protein Mx1 was identified in both the WB transcriptome and proteome. Mx proteins are known to be involved in the response to a broad range of viruses ${ }^{135}$. Four transcripts involved in the bacterial response were identified including two PGRPs, one Bactericidal/Permeability Increasing Protein (BPI), and a partial sequence of the Deleted in Malignant Brain Tumour protein (DMBT1). PGRP2 and DMBT were identified in WB protein extracts, and PGRP2 was one of the 20 most expressed proteins in the WB transcriptome. PGRP and BPI are known to possess antibacterial activity against Escherichia coli in two species of Bivalves ${ }^{136,137}$. Moreover, in Drosophila, PGRPs are involved in the 
activation of the Toll signalling pathway ${ }^{138}$. Both WB PGRPs possess the conserved peptidoglycan-binding type-2 amidase domain involved in bacterial peptidoglycan hydrolysis $^{139}$. DBMT1 is a secreted Scavenger Receptor Cysteine-Rich protein (SRCR) which binds bacteria in humans ${ }^{140,141}$ and is involved in the coelomocyte response to Escherichia coli challenge in the blue bat star (Patiria pectinifera $)^{142}$. As for haematopoietic factors, a manual search of the WB transcriptome was performed to complete the annotation-based search and look for additional immune factors, especially antimicrobial peptides (AMPs). Only two AMPs were identified in a cephalopod during a thorough in silico search on transcriptomic data of cuttlefish PSG, reproductive organs and central nervous system, revealing the complexity of the manual search and identification of factors from unannotated transcripts ${ }^{143}$. No AMP was identified during our manual search, but two galectins were identified (Table 5), and galectin1 was identified in the WB proteome (Table 4). Galectin-1 possesses $44 \%$ identity with a galectin identified in Haliotis rufescens gills, haemocytes and mantle, which is overexpressed in haemocytes after challenge with Vibrio anguillarum ${ }^{144}$. All these factors may be involved in bacterial recognition by and elimination from the cuttlefish WB.

Among the factors involved in the immune system response, we also detected four heat shock proteins (HSPs) (HSP 70, 71, 78 and 90) (Table 4) in the cuttlefish WB and Hct proteome. Only two were identified in the E. scolopes Hct proteome (HSP22 and HSP70) ${ }^{75}$ or the Pomacea canaliculata Hct proteome (HSP70 and HSP90) ${ }^{71}$. Many proteins involved in the oxidative stress response were also found. The occurrence of most of these proteins was confirmed in WB and Hct extracts (Figure 1 and Table 4), like peroxiredoxin-1 (Prx1) or glutathione Stransferase (GST). These two proteins could act as antioxidants, as described for SmPrx1 in Sepiella mandroni ${ }^{145}$ and for GST in the bivalve Thais clavigera ${ }^{146}$. The $\mathrm{Zn} / \mathrm{Cu}$ superoxide dismutase (SOD), up-regulated during Sepiella maindroni challenge with Vibrio harveyi ${ }^{147}$ and described as an Hct marker in Crassostrea gigas $^{22,148}$, was also identified in cuttlefish WB. 
Most of the proteins involved in the oxidative stress response possessed a high iBAQ in WB extracts coinciding with their expression levels, e.g., GST had a TPM value of 1,353 and a WB iBAQ of 10,588, peroxiredoxin-6 had a TPM value of 822 and a WB iBAQ of 3,792, or Zn/Cu SOD had a TPM value of 217 and a WB iBAQ of 3,046 (Tables 4 and 5).

Interestingly, none of the putative effectors of enzyme activities observed in cuttlefish Hct by Le Pabic and collaborators ${ }^{15}$ were identified in the WB transcriptome or the WB or Hct proteomes. However, our manual search of the WB transcriptome allowed us to identify a laccase domain-containing protein (Table 5) which possesses a copper oxidase domain (aa 175 -405) involved in the oxidation of phenol and non-phenol compounds. Several immune factors involved in the bacterial and viral response, such as PGRP2, Mx1 or Tollip, were identified in the WB proteome but not in the Hct proteome (Table 4). These factors are WB-specific and argue in favour of the involvement of this organ in the immune response, as suggested by Juárez et collabators in fertilized females ${ }^{41}$. It would be interesting to study the WB response to a bacterial challenge to confirm this hypothesis.

\section{Conclusion}

-Omic analyses demonstrated for the first time that the cuttlefish WB is involved in haematopoiesis as well as in the immune and stress responses. For the first time, the JAK-STAT signalling pathway was clearly identified in a Mollusc Cephalopod by -omic approaches and identified as a potential key regulator of haematopoiesis. Our comparative analysis of the WB and Hct proteomes tended to bring molecular evidence confirming the previous morphological study by Claes ${ }^{37}$ indicating that the WB is at the origin of Hct. Besides, the WB harbours intense metabolic activity in line with its haematopoietic function. Considering the low level of annotation, numerous factors involved in these functions may have gone unnoticed. Further 
analyses will be needed to confirm the involvement of the JAK-STAT pathway in haematopoiesis and the involvement of the white body in the immune response.

\section{Supporting Information}

The following supporting information is available free of charge at ACS website http://pubs.acs.org

Supporting experimental section. Figures S1-5: The KEGG pathways with transcripts and proteins identified in the WB transcriptome and WB and Hct proteomes are highlighted. Figure S1: MAPK signalling pathway. Figure S2: Cell cycle. Figure S3: PI3K-AKT signalling pathway. Figure S4: Notch signalling pathway. Figure S5: NF-кB signalling pathway. Figure S6: Photograph of the entire SDS-PAGE gel. Table S1: Supporting data regarding proteins identified by SDS-PAGE separation coupled with fast MALDI MS analysis. Table S2: Protein sequences of relevant factors presented in Tables 3, 4 and 5. Table S3: Sequences and corresponding BLAST hits against the NCBI nr database of haemocyte-specific proteins identified by nanoLC coupled with ESI-MS/MS.

\section{Acknowledgments}

We are thankful to the "Région NORMANDIE" for funding this work. We thank Julien Pontin for technical support during MS analysis. We thank Jean-Luc Blaie and François Mével, captains of the professional fishing boats "Père Daniel" and "Clément, Thomas, Elena" and their crews for help in providing cuttlefish. The cuttlefish were bred in the marine station of Luc-sur-Mer (CREC). 


\section{Author contributions}

The manuscript was written by L.B, with the following contributions from the other authors: All authors have given approval to its final version. C.Z.G played an important role in designing and performing -omic approaches. J.H. collect cuttlefish and performed the transcriptomic approach with C.Z.G.. E.C. assembled and annotated the WB transcriptome. L.B. performed dissection with C.Z.G and prepared all samples for mass spectrometry. B.B. performed mass spectrometry analyses. L.B. analyzed and discussed the results with C.Z.G, E.C., B.B..

\section{References}

(1) Smith, V. J. Immunology of Invertebrates: Cellular. In Encyclopedia of Life Sciences; John Wiley \& Sons, Ltd: Chichester, UK, 2016; pp 1-13. https://doi.org/10.1002/9780470015902.a0002344.pub3.

(2) Grigorian, M.; Hartenstein, V. Hematopoiesis and Hematopoietic Organs in Arthropods. Development Genes and Evolution. March 15, 2013, pp 103-115. https://doi.org/10.1007/s00427-012-0428-2.

(3) Marmaras, V. J.; Lampropoulou, M. Regulators and Signalling in Insect Haemocyte Immunity. Cell. Signal. 2008, 21, 186-195. https://doi.org/10.1016/j.cellsig.2008.08.014.

(4) Söderhäll, I. Crustacean Hematopoiesis. Dev. Comp. Immunol. 2016, 58, 129-141. https://doi.org/10.1016/j.dci.2015.12.009.

(5) Matricon-Gondran, M.; Letocart, M. Internal Defenses of the Snail Biomphalaria Glabrata. J. Invertebr. Pathol. 1999, $74 \quad$ (3), 235-247. https://doi.org/10.1006/jipa.1999.4877.

(6) Martin, G. G.; Oakes, C. T.; Tousignant, H. R.; Crabtree, H.; Yamakawa, R. Structure and Function of Haemocytes in Two Marine Gastropods, Megathura Crenulata and Aplysia Californica. J. Molluscan Stud. 2007, 73 (4), 355-365. https://doi.org/10.1093/mollus/eym032. 
(7) Ottaviani, E. Haemocytes of the Freshwater Snail Viviparus Ater. J. Molluscan Stud. 1989, 55 (3), 379-382. https://doi.org/10.1093/mollus/55.3.379.

(8) Carballal, M. J.; López, C.; Azevedo, C.; Villalba, A. In Vitro Study of Phagocytic Ability of Mytilus Galloprovincialis Lmk. Haemocytes. Fish Shellfish Immunol. 1997, 7 (6), 403416. https://doi.org/10.1006/fsim.1997.0094.

(9) Ford, S. E.; Ashton-Alcox, K. A.; Kanaley, S. A. Comparative Cytometric and Microscopic Analyses of Oyster Hemocytes. J. Invertebr. Pathol. 1994, 64 (2), 114-122. https://doi.org/10.1006/jipa.1994.1079.

(10) Wootton, E. C.; Pipe, R. K. Structural and Functional Characterisation of the Blood Cells of the Bivalve Mollusc, Scrobicularia Plana. Fish Shellfish Immunol. 2003, 15 (3), 249262. https://doi.org/10.1016/S1050-4648(02)00164-X.

(11) Liu, J.; Zhao, Y. Morphological and Functional Characterization of Clam Ruditapes Philippinarum Haemocytes. Fish Shellfish Immunol. 2018, 82 (April), 136-146. https://doi.org/10.1016/j.fsi.2018.08.019.

(12) Novoa, B.; Tafalla, C.; Guerra, A.; Figueras, A. Cellular Immunological Parameters of the Octopus, Octopus Vulgaris. J. Shellfish Res. 2002, 21 (1), 243-248.

(13) Castellanos-Martínez, S.; Prado-Alvarez, M.; Lobo-da-Cunha, A.; Azevedo, C.; Gestal, C. Morphologic, Cytometric and Functional Characterization of the Common Octopus (Octopus Vulgaris) Hemocytes. Dev. Comp. Immunol. 2014, 44 (1), 50-58. https://doi.org/10.1016/j.dci.2013.11.013.

(14) Rodriguez-Dominguez, H.; Soto-Bua, M.; Iglesias-Blanco, R.; Crespo-Gonzalez, C.; AriasFernandez, C.; Garcia-Estevez, J. Preliminary Study on the Phagocytic Ability of Octopus Vulgaris Cuvier, 1797 (Mollusca: Cephalopoda) Haemocytes in Vitro. Aquaculture 2006, 254 (1-4), 563-570. https://doi.org/10.1016/j.aquaculture.2005.10.005.

(15) Le Pabic, C.; Safi, G.; Serpentini, A.; Lebel, J.-M.; Robin, J.-P.; Koueta, N. Prophenoloxidase System, Lysozyme and Protease Inhibitor Distribution in the Common Cuttlefish Sepia Officinalis. Comp. Biochem. Physiol. Part B Biochem. Mol. Biol. 2014, 172-173 (1), 96-104. https://doi.org/10.1016/j.cbpb.2014.04.009.

(16) Le Pabic, C.; Goux, D.; Guillamin, M.; Safi, G.; Lebel, J.-M.; Koueta, N.; Serpentini, A. Hemocyte Morphology and Phagocytic Activity in the Common Cuttlefish (Sepia Officinalis). Fish Shellfish Immunol. 2014, 40 (2), 362-373. https://doi.org/10.1016/j.fsi.2014.07.020.

(17) Holz, A. The Two Origins of Hemocytes in Drosophila. Development 2003, 130 (20), 4955-4962. https://doi.org/10.1242/dev.00702.

(18) Robertson, C. W. The Metamorphosis of Drosophila Melanogaster, Including an Accurately Timed Account of the Principal Morphological Changes. J. Morphol. 1936, 59 (2), 351-399. https://doi.org/10.1002/jmor.1050590207.

(19) Hillyer, J. F. Insect Immunology and Hematopoiesis. Dev. Comp. Immunol. 2016, 58, 
102-118. https://doi.org/10.1016/j.dci.2015.12.006.

(20) Jeong, K. H.; Lie, K. J.; Heyneman, D. The Ultrastructure of the Amebocyte-Producing Organ in Biomphalaria Glabrata. Dev. Comp. Immunol. 1983, 7 (2), 217-228. https://doi.org/10.1016/0145-305X(83)90003-4.

(21) Lie, K. J.; Heyneman, D.; Yau, P. The Origin of Amoebocytes in Biomphalaria Glabrata. . J. Parasitol. 1975, 63 (3), 574-586. https://doi.org/10.2307/3279358.

(22) Jemaa, M.; Morin, N.; Cavelier, P.; Cau, J.; Strub, J. M.; Delsert, C.; Jemaà, M.; Morin, N.; Cavelier, P.; Cau, J.; et al. Adult Somatic Progenitor Cells and Hematopoiesis in Oysters. J. Exp. Biol. 2014, 217 (17), 3067-3077. https://doi.org/10.1242/jeb.106575.

(23) Evans, C. J.; Hartenstein, V.; Banerjee, U. Thicker Than Blood. Dev. Cell 2003, 5 (5), 673690. https://doi.org/10.1016/S1534-5807(03)00335-6.

(24) Evans, C. J.; Liu, T.; Banerjee, U. Drosophila Hematopoiesis: Markers and Methods for Molecular Genetic Analysis. Methods 2014, 68 (1), 242-251. https://doi.org/10.1016/j.ymeth.2014.02.038.

(25) Crozatier, M.; Vincent, A. Drosophila: A Model for Studying Genetic and Molecular Aspects of Haematopoiesis and Associated Leukaemias. Dis. Model. Mech. 2011, 4 (4), 439-445. https://doi.org/10.1242/dmm.007351.

(26) Lin, X.; Soderhall, K.; Soderhall, I. Invertebrate Hematopoiesis: An Astakine-Dependent Novel Hematopoietic Factor. J. Immunol. 2011, 186 (4), 2073-2079. https://doi.org/10.4049/jimmunol.1001229.

(27) Soderhall, I.; Kim, Y.-A.; Jiravanichpaisal, P.; Lee, S.-Y.; Soderhall, K. An Ancient Role for a Prokineticin Domain in Invertebrate Hematopoiesis. J. Immunol. 2005, 174 (10), 6153-6160. https://doi.org/10.4049/jimmunol.174.10.6153.

(28) Ottaviani, E.; Franchini, A.; Franceschi, C. Presence of Several Cytokine-like Molecules in Molluscan Hemocytes. Biochem. Biophys. Res. Commun. 1993, 195 (2), 984-988. https://doi.org/10.1006/bbrc.1993.2141.

(29) Baeza Garcia, A.; Pierce, R. J.; Gourbal, B.; Werkmeister, E.; Colinet, D.; Reichhart, J.-M.; Dissous, C.; Coustau, C. Involvement of the Cytokine MIF in the Snail Host Immune Response to the Parasite Schistosoma Mansoni. PLoS Pathog. 2010, 6 (9), e1001115. https://doi.org/10.1371/journal.ppat.1001115.

(30) Wang, B.; Zhang, Z.; Wang, Y.; Zou, Z.; Wang, G.; Wang, S.; Jia, X.; Lin, P. Molecular Cloning and Characterization of Macrophage Migration Inhibitory Factor from Small Abalone Haliotis Diversicolor Supertexta. Fish Shellfish Immunol. 2009, 27 (1), 57-64. https://doi.org/10.1016/j.fsi.2009.04.004.

(31) Zhu, J.; Emerson, S. G. Hematopoietic Cytokines, Transcription Factors and Lineage Commitment. Oncogene 2002, 21 (21 REV. ISS. 2), 3295-3313. https://doi.org/10.1038/sj.onc.1205318.

(32) Katsumura, K. R.; Bresnick, E. H. The GATA Factor Revolution in Hematology. Blood 
2017, 129 (15), 2092-2102. https://doi.org/10.1182/blood-2016-09-687871.

(33) Li, Y.; Song, X.; Wang, W.; Wang, L.; Yi, Q.; Jiang, S.; Jia, Z.; Du, X.; Qiu, L.; Song, L. The Hematopoiesis in Gill and Its Role in the Immune Response of Pacific Oyster Crassostrea Gigas against Secondary Challenge with Vibrio Splendidus. Dev. Comp. Immunol. 2017, 71, 59-69. https://doi.org/10.1016/j.dci.2017.01.024.

(34) Song, X.; Xin, X.; Dong, M.; Wang, W.; Wang, L.; Song, L. The Ancient Role for GATA2/3 Transcription Factor Homolog in the Hemocyte Production of Oyster. Dev. Comp. Immunol. 2018, 82, 55-65. https://doi.org/10.1016/j.dci.2018.01.001.

(35) Real, P. J.; Ligero, G.; Ayllon, V.; Ramos-Mejia, V.; Bueno, C.; Gutierrez-Aranda, I.; Navarro-Montero, O.; Lako, M.; Menendez, P. SCL/TAL1 Regulates Hematopoietic Specification from Human Embryonic Stem Cells. Mol. Ther. 2012, 20 (7), 1443-1453. https://doi.org/10.1038/mt.2012.49.

(36) Song, X.; Wang, H.; Chen, H.; Sun, M.; Liang, Z.; Wang, L.; Song, L. Conserved Hemopoietic Transcription Factor Cg-SCL Delineates Hematopoiesis of Pacific Oyster Crassostrea Gigas. Fish Shellfish Immunol. 2016, 51, 180-188. https://doi.org/10.1016/j.fsi.2016.02.023.

(37) Claes, M. F. Functional Morphology of the White Bodies of the Cephalopod Mollusc Sepia Officinalis. Acfa Zool. 1996, 77 (2), 173-190. https://doi.org/10.1111/j.14636395.1996.tb01262.x.

(38) Cowden, R. R.; Curtis, S. K. Observations on Living Cells Dissociated from the Leukopoietic Organ of Octopus Briareus. Exp. Mol. Pathol. 1973, 19 (2), 178-185. https://doi.org/10.1016/0014-4800(73)90077-4.

(39) Cowden, R. R. Some Cytological and Cytochemical Observations on the Leucopoietic Organs, the "White Bodies," of Octopus Vulgaris. J. Invertebr. Pathol. 1972, 19 (1), 113119. https://doi.org/10.1016/0022-2011(72)90196-6.

(40) Salazar, K. A.; Joffe, N. R.; Dinguirard, N.; Houde, P.; Castillo, M. G. Transcriptome Analysis of the White Body of the Squid Euprymna Tasmanica with Emphasis on Immune and Hematopoietic Gene Discovery. PLoS One 2015, 10 (3), e0119949. https://doi.org/10.1371/journal.pone.0119949.

(41) Juárez, O. E.; López-Galindo, L.; Pérez-Carrasco, L.; Lago-Lestón, A.; Rosas, C.; Cosmo, A. Di; Galindo-Sánchez, C. E. Octopus Maya White Body Show Sex-Specific Transcriptomic Profiles during the Reproductive Phase, with High Differentiation in Signaling Pathways. PLoS One 2019, 14 (5), e0216982. https://doi.org/10.1371/journal.pone.0216982.

(42) Ward, A. C.; Touw, I.; Yoshimura, A. The Jak-Stat Pathway in Normal and Perturbed $\begin{array}{lllll}\text { Hematopoiesis. } & \text { Blood } & 2000, & 19 & \end{array}$ https://doi.org/10.1182/blood.V95.1.19.001k34_19_29.

(43) Levy, D. E.; Darnell, J. E. Stats: Transcriptional Control and Biological Impact. Nat. Rev. Mol. Cell Biol. 2002, 3 (9), 651-662. https://doi.org/10.1038/nrm909. 
(44) Morin-Poulard, I.; Vincent, A.; Crozatier, M. The Drosophila JAK-STAT Pathway in Blood Cell Formation and Immunity. JAK-STAT 2013, 2 (3), e25700. https://doi.org/10.4161/jkst.25700.

(45) Robb, L. Cytokine Receptors and Hematopoietic Differentiation. Oncogene. October 15, 2007, pp 6715-6723. https://doi.org/10.1038/sj.onc.1210756.

(46) Arbouzova, N. I.; Zeidler, M. P. JAK/STAT Signalling in Drosophila: Insights into Conserved Regulatory and Cellular Functions. Development 2006, 133 (14), 2605-2616. https://doi.org/10.1242/dev.02411.

(47) Zhang, S. M.; Coultas, K. A. Identification and Characterization of Five Transcription Factors That Are Associated with Evolutionarily Conserved Immune Signaling Pathways in the Schistosome-Transmitting Snail Biomphalaria Glabrata. Mol. Immunol. 2011, 48 (15-16), 1868-1881. https://doi.org/10.1016/j.molimm.2011.05.017.

(48) Dai, Y. J.; Hui, K. M.; Zhang, Y. H.; Liu, Y.; Wang, Y. Q.; Zhao, L. J.; Lin, L.; Chai, L. Q.; Wei, S.; Lan, J. F. Three STATs Are Involved in the Regulation of the Expression of Antimicrobial Peptides in the Triangle Sail Mussel, Hyriopsis Cumingii. Fish Shellfish Immunol. 2017, 63, 181-188. https://doi.org/10.1016/j.fsi.2017.02.012.

(49) Huang, X. De; Wei, G. J.; He, M. X. Cloning and Gene Expression of Signal Transducers and Activators of Transcription (STAT) Homologue Provide New Insights into the Immune Response and Nucleus Graft of the Pearl Oyster Pinctada Fucata. Fish Shellfish Immunol. 2015, 47 (2), 847-854. https://doi.org/10.1016/j.fsi.2015.10.024.

(50) Bathige, S. D. N. K.; Umasuthan, N.; Park, H.-C.; Lee, J. An Invertebrate Signal Transducer and Activator of Transcription 5 (STAT5) Ortholog from the Disk Abalone, Haliotis Discus Discus : Genomic Structure, Early Developmental Expression, and Immune Responses to Bacterial and Viral Stresses. Dev. Comp. Immunol. 2016, 56, 46-56. https://doi.org/10.1016/j.dci.2015.11.012.

(51) Cornet, V.; Henry, J.; Goux, D.; Duval, E.; Bernay, B.; Le Corguillé, G.; Corre, E.; ZatylnyGaudin, C. How Egg Case Proteins Can Protect Cuttlefish Offspring? PLoS One 2015, 10 (7), e0132836. https://doi.org/10.1371/journal.pone.0132836.

(52) Bolger, A. M.; Lohse, M.; Usadel, B. Trimmomatic: A Flexible Trimmer for Illumina Sequence Data. Bioinformatics 2014, 30 (15), 2114-2120. https://doi.org/10.1093/bioinformatics/btu170.

(53) Grabherr, M. G. .; Brian J. Haas, Moran Yassour Joshua Z. Levin, Dawn A. Thompson, Ido Amit, Xian Adiconis, Lin Fan, Raktima Raychowdhury, Qiandong Zeng, Zehua Chen, Evan Mauceli, Nir Hacohen, Andreas Gnirke, Nicholas Rhind, Federica di Palma, Bruce W., N.; Friedman, and A. R. Trinity: Reconstructing a Full-Length Transcriptome without a Genome from RNA-Seq Data. Nat. Biotechnol. 2013, 29 (7), 644-652. https://doi.org/10.1038/nbt.1883.Trinity.

(54) Bray, N. L.; Pimentel, H.; Melsted, P.; Pachter, L. Near-Optimal Probabilistic RNA-Seq Quantification. Nat. Biotechnol. 2016, 34 (8), 888-888. https://doi.org/10.1038/nbt0816-888d. 
(55) Bryant, D. M.; Johnson, K.; DiTommaso, T.; Tickle, T.; Couger, M. B.; Payzin-Dogru, D.; Lee, T. J.; Leigh, N. D.; Kuo, T.; Davis, F. G.; et al. A Tissue-Mapped Axolotl De Novo Transcriptome Enables Identification of Limb Regeneration Factors. Cell Rep. 2017, 18 (3), 762-776. https://doi.org/10.1016/j.celrep.2016.12.063.

(56) Petersen, T. N.; Brunak, S.; von Heijne, G.; Nielsen, H. SignalP 4.0: Discriminating Signal Peptides from Transmembrane Regions. Nat. Methods 2011, 8 (10), 785-786. https://doi.org/10.1038/nmeth.1701.

(57) Krogh, A.; Larsson, B.; Von Heijne, G.; Sonnhammer, E. L. L. Predicting Transmembrane Protein Topology with a Hidden Markov Model: Application to Complete Genomes. J. Mol. Biol. 2001, 305 (3), 567-580. https://doi.org/10.1006/jmbi.2000.4315.

(58) Finn, R. D.; Bateman, A.; Clements, J.; Coggill, P.; Eberhardt, R. Y.; Eddy, S. R.; Heger, A.; Hetherington, K.; Holm, L.; Mistry, J.; et al. Pfam: The Protein Families Database. Nucleic Acids Res. 2014, 42 (D1), 222-230. https://doi.org/10.1093/nar/gkt1223.

(59) Zatylny-Gaudin, C.; Cornet, V.; Leduc, A.; Zanuttini, B.; Corre, E.; Le Corguillé, G.; Bernay, B.; Garderes, J.; Kraut, A.; Couté, Y.; et al. Neuropeptidome of the Cephalopod Sepia Officinalis: Identification, Tissue Mapping, and Expression Pattern of Neuropeptides and Neurohormones during Egg Laying. J. Proteome Res. 2016, 15 (1), 48-67. https://doi.org/10.1021/acs.jproteome.5b00463.

(60) Mitchell, A. L.; Attwood, T. K.; Babbitt, P. C.; Blum, M.; Bork, P.; Bridge, A.; Brown, S. D.; Chang, H.-Y.; El-Gebali, S.; Fraser, M. I.; et al. InterPro in 2019: Improving Coverage, Classification and Access to Protein Sequence Annotations. Nucleic Acids Res. 2019, 47 (D1), D351-D360. https://doi.org/10.1093/nar/gky1100.

(61) Letunic, I.; Bork, P. 20 Years of the SMART Protein Domain Annotation Resource. Nucleic Acids Res. 2018, 46 (D1), D493-D496. https://doi.org/10.1093/nar/gkx922.

(62) Moriya, Y.; Itoh, M.; Okuda, S.; Yoshizawa, A. C.; Kanehisa, M. KAAS: An Automatic Genome Annotation and Pathway Reconstruction Server. Nucleic Acids Res. 2007, 35 (Web Server issue), W182-5. https://doi.org/10.1093/nar/gkm321.

(63) Kanehisa, M.; Sato, Y.; Morishima, K. BlastKOALA and GhostKOALA: KEGG Tools for Functional Characterization of Genome and Metagenome Sequences. J. Mol. Biol. 2016, 428 (4), 726-731. https://doi.org/10.1016/j.jmb.2015.11.006.

(64) Smith, P. K.; Krohn, R. I.; Hermanson, G. T.; Mallia, A. K.; Gartner, F. H.; Provenzano, M. D.; Fujimoto, E. K.; Goeke, N. M.; Olson, B. J.; Klenk, D. C. Measurement of Protein Using Bicinchoninic Acid. Anal. Biochem. 1985, 150 (1), 76-85. https://doi.org/10.1016/00032697(85)90442-7.

(65) Cornet, V.; Henry, J.; Corre, E.; Le Corguille, G.; Zanuttini, B.; Zatylny-Gaudin, C. Dual Role of the Cuttlefish Salivary Proteome in Defense and Predation. J. Proteomics 2014, 108, 209-222. https://doi.org/10.1016/j.jprot.2014.05.019.

(66) Perez-Riverol, Y.; Csordas, A.; Bai, J.; Bernal-Llinares, M.; Hewapathirana, S.; Kundu, D. J.; Inuganti, A.; Griss, J.; Mayer, G.; Eisenacher, M.; et al. The PRIDE Database and 
Related Tools and Resources in 2019: Improving Support for Quantification Data. Nucleic Acids Res. 2019, 47 (D1), D442-D450. https://doi.org/10.1093/nar/gky1106.

(67) Xie, Y.; Shi, X.; Sheng, K.; Han, G.; Li, W.; Zhao, Q.; Jiang, B.; Feng, J.; Li, J.; Gu, Y. PI3K/Akt Signaling Transduction Pathway, Erythropoiesis and Glycolysis in Hypoxia (Review). Mol. Med. Rep. 2019, 19 (2), 783-791. https://doi.org/10.3892/mmr.2018.9713.

(68) Sun, Y.; Liu, W. Z.; Liu, T.; Feng, X.; Yang, N.; Zhou, H. F. Signaling Pathway of MAPK/ERK in Cell Proliferation, Differentiation, Migration, Senescence and Apoptosis. J. Recept. $\begin{array}{llll}\text { Signal Transduct. } & \text { 2015, 600-604. }\end{array}$ https://doi.org/10.3109/10799893.2015.1030412.

(69) Yu, J. S. L.; Cui, W. Proliferation, Survival and Metabolism: The Role of PI3K/AKT/MTOR Signalling in Pluripotency and Cell Fate Determination. Development 2016, 143 (17), 3050-3060. https://doi.org/10.1242/dev.137075.

(70) Söderhäll, I.; Junkunlo, K. A Comparative Global Proteomic Analysis of the Hematopoietic Lineages in the Crustacean Pacifastacus Leniusculus. Dev. Comp. Immunol. 2019, 92, 170-178. https://doi.org/10.1016/j.dci.2018.11.016.

(71) Boraldi, F.; Lofaro, F. D.; Accorsi, A.; Ross, E.; Malagoli, D.; Boraldi, F.; Lofaro, F. D. Towards the Molecular Deciphering of Pomacea Canaliculata Immunity: First Proteomic Analysis of Circulating Hemocytes. Proteomics 2018, 1800314. https://doi.org/10.1002/pmic.201800314.

(72) Zhu, L.; Tang, X.; Xing, J.; Sheng, X.; Zhan, W. Differential Proteome of Haemocyte Subpopulations Responded to White Spot Syndrome Virus Infection in Chinese Shrimp Fenneropenaeus Chinensis. Dev. Comp. Immunol. 2018, 84, 82-93. https://doi.org/10.1016/j.dci.2018.02.003.

(73) Herbinière, J.; Grève, P.; Strub, J. M.; Thiersé, D.; Raimond, M.; van Dorsselaer, A.; Martin, G.; Braquart-Varnier, C. Protein Profiling of Hemocytes from the Terrestrial Crustacean Armadillidium Vulgare,. Dev. Comp. Immunol. 2008, 32 (8), 875-882. https://doi.org/10.1016/j.dci.2008.01.007.

(74) Castellanos-Martínez, S.; Diz, A. P.; Álvarez-Chaver, P.; Gestal, C. Proteomic Characterization of the Hemolymph of Octopus Vulgaris Infected by the Protozoan Parasite Aggregata Octopiana. J. Proteomics 2014, 105 (2), 151-163. https://doi.org/10.1016/j.jprot.2013.12.008.

(75) Schleicher, T. R.; VerBerkmoes, N. C.; Shah, M.; Nyholm, S. V. Colonization State Influences the Hemocyte Proteome in a Beneficial Squid-Vibrio Symbiosis. Mol. Cell. Proteomics 2014, 13 (10), 2673-2686. https://doi.org/10.1074/mcp.M113.037259.

(76) Huang, J.; Li, S.; Liu, Y.; Liu, C.; Xie, L.; Zhang, R. Hemocytes in the Extrapallial Space of Pinctada Fucata Are Involved in Immunity and Biomineralizatio. Sci. Rep. 2018, 8 (1), 111. https://doi.org/10.1038/s41598-018-22961-y.

(77) Somboonwiwat, K.; Chaikeeratisak, V.; Wang, H.-C.; Fang Lo, C.; Tassanakajon, A. Proteomic Analysis of Differentially Expressed Proteins in Penaeus Monodon 
Hemocytes after Vibrio Harveyi Infection. Proteome Sci. 2010, 8 (1), 39. https://doi.org/10.1186/1477-5956-8-39.

(78) Binari, R.; Perrimon, N. Stripe-Specific Regulation of Pair-Rule Genes by Hopscotch, a Putative Jak Family Tyrosine Kinase in Drosophila. Genes Dev. 1994, 8 (3), 300-312. https://doi.org/10.1101/gad.8.3.300.

(79) Hou, X. S.; Melnick, M. B.; Perrimon, N. Marelle Acts Downstream of the Drosophila HOP/JAK Kinase and Encodes a Protein Similar to the Mammalian STATs. Cell 1996, 84 (3), 411-419. https://doi.org/10.1016/S0092-8674(00)81286-6.

(80) Yan, R.; Small, S.; Desplan, C.; Dearolf, C. R.; Darnell, J. E. Identification of a Stat Gene That Functions in Drosophila Development. Cell 1996, 84 (3), 421-430. https://doi.org/10.1016/S0092-8674(00)81287-8.

(81) Brown, S.; Hu, N.; Hombría, J. C.-G. Identification of the First Invertebrate Interleukin JAK/STAT Receptor, the Drosophila Gene Domeless. Curr. Biol. 2001, 11 (21), 17001705. https://doi.org/10.1016/S0960-9822(01)00524-3.

(82) Chen, H. W.; Chen, X.; Oh, S. W.; Marinissen, M. J.; Silvio Gutkind, J.; Hou, S. X. Mom Identifies a Receptor for the Drosophila JAK/STAT Signal Transduction Pathway and Encodes a Protein Distantly Related to the Mammalian Cytokine Receptor Family. Genes Dev. 2002, 16 (3), 388-398. https://doi.org/10.1101/gad.955202.

(83) Harrison, D. A.; McCoon, P. E.; Binari, R.; Gilman, M.; Perrimon, N. Drosophila Unpaired Encodes a Secreted Protein That Activates the JAK Signaling Pathway. Genes Dev. 1998, 12 (20), 3252-3263. https://doi.org/10.1101/gad.12.20.3252.

(84) Agaisse, H.; Petersen, U.-M.; Boutros, M.; Mathey-Prevot, B.; Perrimon, N. Signaling Role of Hemocytes in Drosophila JAK/STAT-Dependent Response to Septic Injury. Dev. Cell 2003, 5 (3), 441-450. https://doi.org/10.1016/S1534-5807(03)00244-2.

(85) Gilbert, M. M.; Weaver, B. K.; Gergen, J. P.; Reich, N. C. A Novel Functional Activator of the Drosophila JAK/STAT Pathway, Unpaired2, Is Revealed by an in Vivo Reporter of Pathway Activation. Mech. Dev. 2005, 122 (7-8), 939-948. https://doi.org/10.1016/j.mod.2005.03.004.

(86) Hombría, J. C.-G.; Brown, S.; Häder, S.; Zeidler, M. P. Characterisation of Upd2, a Drosophila JAK/STAT Pathway Ligand. Dev. Biol. 2005, 288 (2), 420-433. https://doi.org/10.1016/j.ydbio.2005.09.040.

(87) Williams, C. C.; Allison, J. G.; Vidal, G. A.; Burow, M. E.; Beckman, B. S.; Marrero, L.; Jones, F. E. The ERBB4/HER4 Receptor Tyrosine Kinase Regulates Gene Expression by Functioning as a STAT5A Nuclear Chaperone. J. Cell Biol. 2004, 167 (3), 469-478. https://doi.org/10.1083/jcb.200403155.

(88) Lebestky, T.; Jung, S. H.; Banerjee, U. A Serrate-Expressing Signaling Center Controls Drosophila Hematopoiesis. Genes Dev. 2003, 17 (3), 348-353. https://doi.org/10.1101/gad.1052803. 
(89) Lampreia, F. P.; Carmelo, J. G.; Anjos-Afonso, F. Notch Signaling in the Regulation of Hematopoietic Stem Cell. Curr. Stem Cell Reports 2017, 3 (3), 202-209. https://doi.org/10.1007/s40778-017-0090-8.

(90) Weber, J. M.; Calvi, L. M. Notch Signaling and the Bone Marrow Hematopoietic Stem Cell Niche. Bone 2010, 46 (2), 281-285. https://doi.org/10.1016/j.bone.2009.08.007.

(91) Matsumoto, N.; Yoneda-Kato, N.; Iguchi, T.; Kishimoto, Y.; Kyo, T.; Sawada, H.; Tatsumi, E.; Fukuhara, S. Elevated MLF1 Expression Correlates with Malignant Progression from Myelodysplastic Syndrome. Leukemia 2000, 14 (10), 1757-1765. https://doi.org/10.1038/sj.leu.2401897.

(92) Yoneda-Kato, N.; Tomoda, K.; Umehara, M.; Arata, Y.; Kato, J.-Y. Myeloid Leukemia Factor 1 Regulates P53 by Suppressing COP1 via COP9 Signalosome Subunit 3. EMBO J. 2005, 24, 1739-1749. https://doi.org/10.1038/sj.emboj.7600656.

(93) Hanspal, M.; Smockova, Y.; Uong, Q. Molecular Identification and Functional Characterization of a Novel Protein That Mediates the Attachment of Erythroblasts to $\begin{array}{lllll}\text { Macrophages. } & \text { Blood } & 1998, & \end{array}$ https://doi.org/http://dx.doi.org/10.1016/S0883-9417(00)80022-9.

(94) Mao, X.; Shi, X.; Liu, F.; Li, G.; Hu, L. Evaluation of Erythroblast Macrophage Protein Related to Erythroblastic Islands in Patients with Hematopoietic Stem Cell Transplantation. Eur. J. Med. Res. 2013, 18 (1), 1-7. https://doi.org/10.1186/2047783X-18-9.

(95) Giesert, C.; Marxer, A.; Sutherland, D. R.; Schuh, A. C.; Kanz, L.; Bühring, H.-J. Antibody W7C5 Defines a CD109 Epitope Expressed on CD34 + and CD34 - Hematopoietic and Mesenchymal Stem Cell Subsets. Ann. N. Y. Acad. Sci. 2003, 996 (1), 227-230. https://doi.org/10.1111/j.1749-6632.2003.tb03250.x.

(96) Giesert, C.; Almeida-Porada, G.; Scheffold, A.; Kanz, L.; Zanjani, E. D.; Bühring, H.-J. The Monoclonal Antibody W7C5 Defines a Novel Surface Antigen on Hematopoietic Stem Cells. Ann. N. Y. Acad. Sci. 2006, 938 (1), 175-183. https://doi.org/10.1111/j.17496632.2001.tb03587.x.

(97) Hernández-Campo, P. M.; Almeida, J.; Matarraz, S.; de Santiago, M.; Sánchez, M. L.; Orfao, A. Quantitative Analysis of the Expression of GlycosylphosphatidylinositolAnchored Proteins during the Maturation of Different Hematopoietic Cell Compartments of Normal Bone Marrow. Cytom. Part B Clin. Cytom. 2007, 72B (1), 3442. https://doi.org/10.1002/cyto.b.20143.

(98) Lin, M.; Robert Sutherland, D.; Horsfall, W.; Totty, N.; Yeo, E.; Nayar, R.; Wu, X. F.; Schuh, A. C. Cell Surface Antigen CD 109 Is a Novel Member of the A2macroglobulin/C3, C4, C5 Family of Thioester-Containing Proteins. Blood 2002, 99 (5), 1683-1691. https://doi.org/10.1182/blood.V99.5.1683.

(99) Yazzie, N.; Salazar, K. A.; Castillo, M. G. Identification, Molecular Characterization, and Gene Expression Analysis of a CD109 Molecule in the Hawaiian Bobtail Squid Euprymna Scolopes. Fish Shellfish Immunol. 2015, 44 (1), 342-355. 
https://doi.org/10.1016/j.fsi.2015.02.036.

(100) Bender, T. P.; Kremer, C. S.; Kraus, M.; Buch, T.; Rajewsky, K. Critical Functions for CMyb at Three Checkpoints during Thymocyte Development. Nat. Immunol. 2004, 5 (7), 721-729. https://doi.org/10.1038/ni1085.

(101) Mucenski, M. L.; McLain, K.; Kier, A. B.; Swerdlow, S. H.; Schreiner, C. M.; Miller, T. A.; Pietryga, D. W.; Scott, W. J.; Potter, S. S. A Functional C-Myb Gene Is Required for Normal Murine Fetal Hepatic Hematopoiesis. Cell 1991, 65 (4), 677-689. https://doi.org/10.1016/0092-8674(91)90099-K.

(102) Sandberg, M. L.; Sutton, S. E.; Pletcher, M. T.; Wiltshire, T.; Tarantino, L. M.; Hogenesch, J. B.; Cooke, M. P. C-Myb and P300 Regulate Hematopoietic Stem Cell Proliferation and

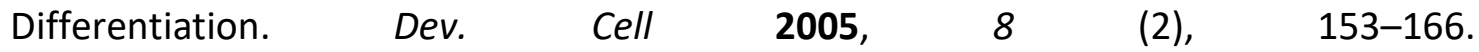
https://doi.org/10.1016/j.devcel.2004.12.015.

(103) Maurice, D.; Hooper, J.; Lang, G.; Weston, K. C-Myb Regulates Lineage Choice in Developing Thymocytes via Its Target Gene Gata3. EMBO J. 2007, 26 (15), 3629-3640. https://doi.org/10.1038/sj.emboj.7601801.

(104) Shinnakasu, R.; Yamashita, M.; Shinoda, K.; Endo, Y.; Hosokawa, H.; Hasegawa, A.; Ikemizu, S.; Nakayama, T. Critical YxKxHxxxRP Motif in the C-Terminal Region of GATA3 for Its DNA Binding and Function. J. Immunol. 2006, 177 (9), 5801-5810. https://doi.org/10.4049/jimmunol.177.9.5801.

(105) Korf-Klingebiel, M.; Reboll, M. R.; Klede, S.; Brod, T.; Pich, A.; Polten, F.; Napp, L. C.; Bauersachs, J.; Ganser, A.; Brinkmann, E.; et al. Myeloid-Derived Growth Factor (C19orf10) Mediates Cardiac Repair Following Myocardial Infarction. Nat. Med. 2015, 21 (2), 140-149. https://doi.org/10.1038/nm.3778.

(106) Reichman, T. W.; Muniz, L. C.; Mathews, M. B. The RNA Binding Protein Nuclear Factor 90 Functions as Both a Positive and Negative Regulator of Gene Expression in Mammalian Cells. Mol. Cell. Biol. 2002, 22 (1), 343-356. https://doi.org/10.1128/MCB.22.1.343-356.2002.

(107) Wu, T. H.; Shi, L.; Adrian, J.; Shi, M.; Nair, R. V.; Snyder, M. P.; Kao, P. N. NF90/ILF3 Is a Transcription Factor That Promotes Proliferation over Differentiation by Hierarchical Regulation in K562 Erythroleukemia Cells. PLoS One 2018, 13 (3). https://doi.org/10.1371/journal.pone.0193126.

(108) Yang, F.; Xu, Y. P.; Li, J.; Duan, S. S.; Fu, Y. J.; Zhang, Y.; Zhao, Y.; Qiao, W. T.; Chen, Q. M.; Geng, Y. Q.; et al. Cloning and Characterization of a Novel Intracellular Protein P48.2 That Negatively Regulates Cell Cycle Progression. Int. J. Biochem. Cell Biol. 2009, 41 (11), 2240-2250. https://doi.org/10.1016/j.biocel.2009.04.022.

(109) Takeshita, T.; Arita, T.; Higuchi, M.; Asao, H.; Endo, K.; Kuroda, H.; Tanaka, N.; Murata, K.; Ishii, N.; Sugamura, K. STAM, Signal Transducing Adaptor Molecule, Is Associated with Janus Kinases and Involved in Signaling for Cell Growth and c-Myc Induction. Immunity 1997, 6 (4), 449-457. https://doi.org/10.1016/S1074-7613(00)80288-5. 
(110) Tanaka, N.; Kaneko, K.; Asao, H.; Kasai, H.; Endo, Y.; Fujita, T.; Takeshita, T.; Sugamura, K. Possible Involvement of a Novel STAM-Associated Molecule "AMSH" in Intracellular Signal Transduction Mediated by Cytokines. J. Biol. Chem. 1999, 274 (27), 19129-19135. https://doi.org/10.1074/jbc.274.27.19129.

(111) Takeshita, T.; Arita, T.; Asao, H.; Tanaka, N.; Higuchi, M.; Kuroda, H.; Kaneko, K.; Munakata, H.; Endo, Y.; Fujita, T.; et al. Cloning of a Novel Signal-Transducing Adaptor Molecule Containing an SH3 Domain and ITAM. Biochem. Biophys. Res. Commun. 1996, 225 (3), 1035-1039. https://doi.org/10.1006/bbrc.1996.1290.

(112) Giampaolo, S.; Wojcik, G.; Serfling, E.; Patra, A. K. Interleukin-2-Regulatory T Cell Axis Critically Regulates Maintenance of Hematopoietic Stem Cells. Oncotarget 2017, 8 (18), 29625-29642. https://doi.org/10.18632/oncotarget.16377.

(113) Bolli, N.; Payne, E. M.; Rhodes, J.; Gjini, E.; Johnston, A. B.; Guo, F.; Lee, J.-S.; Stewart, R. A.; Kanki, J. P.; Chen, A. T.; et al. Cpsf1 Is Required for Definitive Hematopoietic Stem Cell Survival in Zebrafish. Blood 2011, 117 (15), 3996-4007. https://doi.org/10.1182/blood-2010-08-304030.

(114) Itkin, T.; Hornstein, E.; Ludin, A.; Piacibello, W.; Schajnovitz, A.; Kalinkovich, A.; Enikolopov, G. N.; Ovadya, Y.; Coffin, D. J.; Shezen, E.; et al. FGF-2 Expands Murine Hematopoietic Stem and Progenitor Cells via Proliferation of Stromal Cells, c-Kit Activation, and CXCL12 down-Regulation. Blood 2012, 120 (9), 1843-1855. https://doi.org/10.1182/blood-2011-11-394692.

(115) Aderem, A.; Ulevitch, R. J. Toll-like Receptors in the Induction of the Innate Immune Response. Nature 2000, 406 (6797), 782-787. https://doi.org/10.1038/35021228.

(116) Takeuchi, O.; Akira, S. Toll-like Receptors; Their Physiological Role and Signal Transduction System. Int. Immunopharmacol. 2001, 1 (4), 625-635. https://doi.org/10.1016/S1567-5769(01)00010-8.

(117) Valanne, S.; Wang, J.-H.; Ramet, M. The Drosophila Toll Signaling Pathway. J. Immunol. 2011, 186 (2), 649-656. https://doi.org/10.4049/jimmunol.1002302.

(118) Goodson, M. S.; Kojadinovic, M.; Troll, J. V; Scheetz, T. E.; Casavant, T. L.; Bento Soares, M.; McFall-Ngai, M. J. Identifying Components of the NF-KB Pathway in the Beneficial Euprymna Scolopes-Vibrio Fischen Light Organ Symbiosis. Appl. Environ. Microbiol. 2005, 71 (11), 6934-6946. https://doi.org/10.1128/AEM.71.11.6934-6946.2005.

(119) Rauta, P. R.; Samanta, M.; Dash, H. R.; Nayak, B.; Das, S. Toll-like Receptors (TLRs) in Aquatic Animals: Signaling Pathways, Expressions and Immune Responses. Immunol. Lett. 2014, 158 (1-2), 14-24. https://doi.org/10.1016/j.imlet.2013.11.013.

(120) Cornet, V.; Henry, J.; Corre, E.; Le Corguillé, G.; Zatylny-Gaudin, C. The Toll/NF-KB Pathway in Cuttlefish Symbiotic Accessory Nidamental Gland. Dev. Comp. Immunol. 2015, 53 (1), 42-46. https://doi.org/10.1016/j.dci.2015.06.016.

(121) Humphries, J. E.; Deneckere, L. E. Characterization of a Toll-like Receptor (TLR) Signaling Pathway in Biomphalaria Glabrata and Its Potential Regulation by NF-KappaB. Dev. 
Comp. Immunol. 2018, 86, 118-129. https://doi.org/10.1016/j.dci.2018.05.003.

(122) Collins, A. J.; Schleicher, T. R.; Rader, B. A.; Nyholm, S. V. Understanding the Role of Host Hemocytes in a Squid/Vibrio Symbiosis Using Transcriptomics and Proteomics. Front. Immunol. 2012, 3 (MAY), 91. https://doi.org/10.3389/fimmu.2012.00091.

(123) Wu, Y.; Liang, H.; Wang, Z.; Lei, Q.; Xia, L. A Novel Toll-like Receptor from the Pearl Oyster Pinctada Fucata Martensii Is Induced in Response to Stress. Comp. Biochem. Physiol. Part - B Biochem. Mol. Biol. 2017, 214 (August), 19-26. https://doi.org/10.1016/j.cbpb.2017.08.006.

(124) Huo, L.; Bao, M.; Lv, Z.; Chi, C.; Wang, T.; Liu, H. Identification, Functional Characterization and Expression Pattern of Myeloid Differentiation Factor 88 (MyD88) in Sepiella Japonica. Fish Shellfish Immunol. 2018, 79 (1), 112-119. https://doi.org/10.1016/j.fsi.2018.04.065.

(125) Zhang, R.; Li, R.; Wang, J.; Wang, S.; Zhang, M.; Hu, X.; Zhang, L.; Wang, S.; Wang, R.; Bao, Z. Identification, Characterization and Expression Profiling of the Tollip Gene in Yesso Scallop (Patinopecten Yessoensis). Genes Genet. Syst. 2015, 90 (2), 99-108. https://doi.org/10.1266/ggs.90.99.

(126) Zhang, G.; Ghosh, S. Negative Regulation of Toll-like Receptor-Mediated Signaling by Tollip. J. Biol. Chem. 2002, 277 (9), 7059-7065. https://doi.org/10.1074/jbc.M109537200.

(127) Gilmore, T. D.; Wolenski, F. S. NF-KB: Where Did It Come from and Why? Immunol. Rev. 2012, 246 (1), 14-35. https://doi.org/10.1111/j.1600-065X.2012.01096.x.

(128) Dijkers, P. F.; O’Farrell, P. H. Drosophila Calcineurin Promotes Induction of Innate Immune Responses. Curr. Biol. 2007, 17 (23), 2087-2093. https://doi.org/10.1016/j.cub.2007.11.001.

(129) Li, S.; Jia, Z.; Chen, X.; Geng, X.; Sun, J. Identification and Characterization of the CDNAs Encoding the Two Subunits of Chinese Mitten Crab (Eriocheir Sinensis) Calcineurin: Their Implications in Stress and Immune Response. Fish Shellfish Immunol. 2015, 43 (1), 91-102. https://doi.org/10.1016/j.fsi.2014.12.020.

(130) Li, C.; Liang, J.; Ma, Z.; Hu, Y.; Yan, Z.; Li, Q.; Fang, Z.; Wang, H.; Zhang, G.; Xie, L.; et al. Calcineurin Mediates the Immune Response of Hemocytes through NF-KB Signaling Pathway in Pearl Oyster (Pinctada Fucata). Fish Shellfish Immunol. 2010, 28 (2), 253260. https://doi.org/10.1016/j.fsi.2009.11.001.

(131) Frantz, B.; Nordby, E. C.; Bren, G.; Steffan, N.; Paya, C. V.; Kincaid, R. L.; Tocci, M. J.; O'Keefe, S. J.; O'Neill, E. A. Calcineurin Acts in Synergy with PMA to Inactivate I Kappa B/MAD3, an Inhibitor of NF-Kappa B. EMBO J. 1994, 13 (4), 861-870. https://doi.org/10.1002/j.1460-2075.1994.tb06329.x.

(132) Lin, X.; Sikkink, R. A.; Rusnak, F.; Barber, D. L. Inhibition of Calcineurin Phosphatase Activity by a Calcineurin B Homologous Protein. J. Biol. Chem. 1999, 274 (51), 3612536131. https://doi.org/10.1074/jbc.274.51.36125. 
(133) Dheilly, N. M.; Haynes, P. A.; Bove, U.; Nair, S. V.; Raftos, D. A. Comparative Proteomic Analysis of a Sea Urchin (Heliocidaris Erythrogramma) Antibacterial Response Revealed the Involvement of Apextrin and Calreticulin. J. Invertebr. Pathol. 2011, 106 (2), 223229. https://doi.org/10.1016/j.jip.2010.09.008.

(134) Li, S.; Jia, Z.; Li, X.; Geng, X.; Sun, J. Calmodulin Is a Stress and Immune Response Gene in Chinese Mitten Crab Eriocheir Sinensis. Fish Shellfish Immunol. 2014, 40 (1), 120-128. https://doi.org/10.1016/j.fsi.2014.06.027.

(135) Verhelst, J.; Hulpiau, P.; Saelens, X. Mx Proteins: Antiviral Gatekeepers That Restrain the Uninvited. Microbiol. Mol. Biol. Rev. 2013, 77 (4), 551-566. https://doi.org/10.1128/MMBR.00024-13.

(136) Yang, J.; Wang, W.; Wei, X.; Qiu, L.; Wang, L.; Zhang, H.; Song, L. Peptidoglycan Recognition Protein of Chlamys Farreri (CfPGRP-S1) Mediates Immune Defenses against Bacterial Infection. Dev. Comp. Immunol. 2010, 34 (12), 1300-1307. https://doi.org/10.1016/j.dci.2010.08.006.

(137) Gonzalez, M.; Gueguen, Y.; Destoumieux-Garzon, D.; Romestand, B.; Fievet, J.; Pugniere, M.; Roquet, F.; Escoubas, J.-M.; Vandenbulcke, F.; Levy, O.; et al. Evidence of a Bactericidal Permeability Increasing Protein in an Invertebrate, the Crassostrea Gigas Cg-BPI. Proc. Natl. Acad. Sci. 2007, 104 (45), 17759-17764. https://doi.org/10.1073/pnas.0702281104.

(138) Michel, T.; Reichhart, J.-M.; Hoffmann, J. A.; Royet, J. Drosophila Toll Is Activated by Gram-Positive Bacteria through a Circulating Peptidoglycan Recognition Protein. Nature 2001, 414 (6865), 756-759. https://doi.org/10.1038/414756a.

(139) Dziarski, R.; Gupta, D. The Peptidoglycan Recognition Proteins (PGRPs). Genome Biol. 2006, 7 (8), 232. https://doi.org/10.1186/gb-2006-7-8-232.

(140) Prakobphol, A.; Xu, F.; Hoang, V. M.; Larsson, T.; Bergstrom, J.; Johansson, I.; Frängsmyr, L.; Holmskov, U.; Leffler, H.; Nilsson, C.; et al. Salivary Agglutinin, Which Binds Streptococcus Mutans and Helicobacter Pylori, Is the Lung Scavenger Receptor Cysteine-Rich Protein Gp-340. J. Biol. Chem. 2000, 275 (51), 39860-39866. https://doi.org/10.1074/jbc.M006928200.

(141) Bikker, F. J.; Ligtenberg, A. J. M.; Nazmi, K.; Veerman, E. C. I.; Hof, W. V. N. T.; Bolscher, J. G. M.; Poustka, A.; Nieuw Amerongen, A. V.; Mollenhauer, J. Identification of the Bacteria-Binding Peptide Domain on Salivary Agglutinin (Gp-340/DMBT1), a Member of the Scavenger Receptor Cysteine-Rich Superfamily. J. Biol. Chem. 2002, 277 (35), 32109-32115. https://doi.org/10.1074/jbc.M203788200.

(142) Furukawa, R.; Matsumoto, M.; Kaneko, H. Characterization of a Scavenger Receptor Cysteine-Rich-Domain-Containing Protein of the Starfish, Asterina Pectinifera: ApSRCR1 Acts as an Opsonin in the Larval and Adult Innate Immune Systems. Dev. Comp. Immunol. 2012, 36 (1), 51-61. https://doi.org/10.1016/j.dci.2011.06.005.

(143) Houyvet, B.; Zanuttini, B.; Corre, E.; Le Corguillé, G.; Henry, J.; Zatylny-Gaudin, C. Design of Antimicrobial Peptides from a Cuttlefish Database. Amino Acids 2018, 50 (11), 1573- 
1582. https://doi.org/10.1007/s00726-018-2633-4.

(144) Maldonado-Aguayo, W.; Teneb, J.; Gallardo-Escárate, C. A Galectin with QuadrupleDomain from Red Abalone Haliotis Rufescens Involved in the Immune Innate Response against to Vibrio Anguillarum. Fish Shellfish Immunol. 2014, 40 (1), 1-8. https://doi.org/10.1016/j.fsi.2014.06.013.

(145) Song, W.; Mu, C.; Li, R.; Wang, C. Peroxiredoxin 1 from Cuttlefish (Sepiella Maindroni): Molecular Characterization of Development and Its Immune Response against Vibrio Alginolyticus. Fish Shellfish Immunol. 2017, 67, 596-603. https://doi.org/10.1016/j.fsi.2017.06.034.

(146) Rhee, J. S.; Raisuddin, S.; Hwang, D. S.; Horiguchi, T.; Cho, H. S.; Lee, J. S. A Mu-Class Glutathione S-Transferase (GSTM) from the Rock Shell Thais Clavigera. Comp. Biochem. Physiol. - C Toxicol. Pharmacol. 2008, 148 (3), 195-203. https://doi.org/10.1016/j.cbpc.2008.05.011.

(147) He, J. yu; Chi, C. feng; Liu, H. hui. Identification and Analysis of an Intracellular Cu/Zn Superoxide Dismutase from Sepiella Maindroni under Stress of Vibrio Harveyi and Cd2+. Dev. Comp. Immunol. 2014, 47 (1), 1-5. https://doi.org/10.1016/j.dci.2014.06.010.

(148) Gonzalez, M.; Romestand, B.; Fievet, J.; Huvet, A.; Lebart, M. C.; Gueguen, Y.; Bachère, E. Evidence in Oyster of a Plasma Extracellular Superoxide Dismutase Which Binds LPS. Biochem. Biophys. Res. Commun. 2005, 338 (2), 1089-1097. https://doi.org/10.1016/j.bbrc.2005.10.075. 
For Table of Contents Only

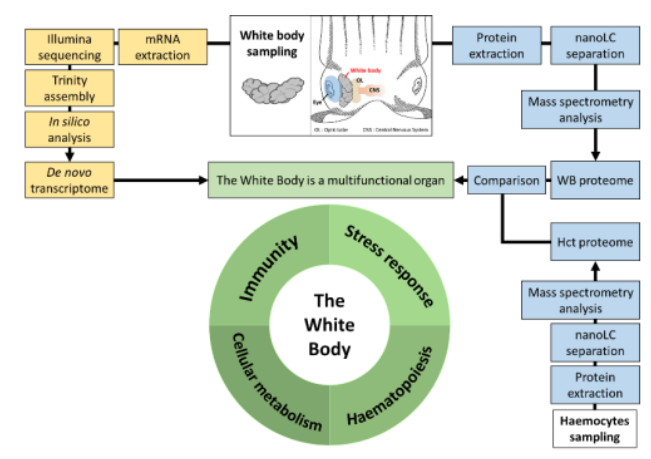

